
\title{
K4D
}

\section{Trends in conflict and stability in the Indo-Pacific}

Iffat Idris

GSDRC, University of Birmingham

January 2021 


\section{About this report}

The K4D Emerging Issues report series highlights research and emerging evidence to policy-makers to help inform policies that are more resilient to the future. K4D staff researchers work with thematic experts and FCDO to identify where new or emerging research can inform and influence policy.

This report is based on ten days of desk-based research carried out in December 2020.

K4D services are provided by a consortium of leading organisations working in international development, led by the Institute of Development Studies (IDS), with the Education Development Trust, Itad, University of Leeds Nuffield Centre for International Health and Development, Liverpool School of Tropical Medicine (LSTM), University of Birmingham International Development Department (IDD) and the University of Manchester Humanitarian and Conflict Response Institute (HCRI).

For any enquiries, please contact helpdesk@k4d.info.

\section{Suggested citation}

Idris, I. (2020). Trends in conflict and stability in the Indo-Pacific. K4D Emerging Issues Report 42. Brighton, UK: Institute of Development Studies. DOI: 10.19088/K4D.2021.009

\section{Copyright}

This report was prepared for the UK Government's Foreign, Commonwealth and Development Office (FCDO) and its partners in support of pro-poor programmes. Except where otherwise stated, it is licensed for noncommercial purposes under the terms of the Open Government Licence v3.0. K4D cannot be held responsible for errors or any consequences arising from the use of information contained in this report. Any views and opinions expressed do not necessarily reflect those of FCDO, K4D or any other contributing organisation. 


\section{Contents}

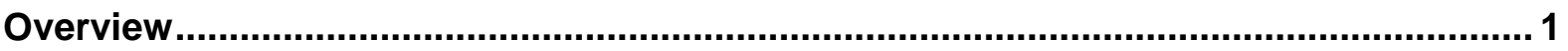

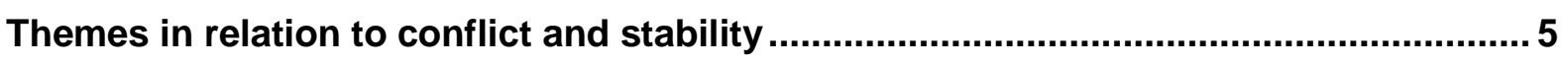

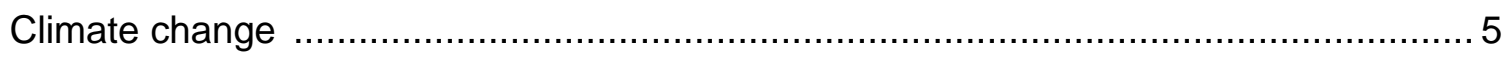

Links between climate change effects and conflict.......................................... 5

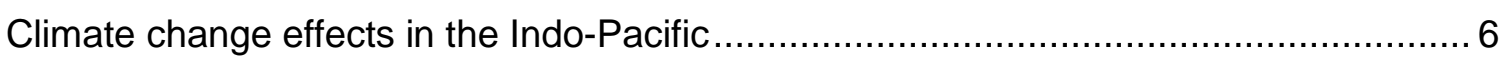

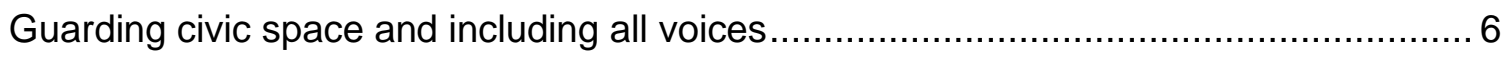

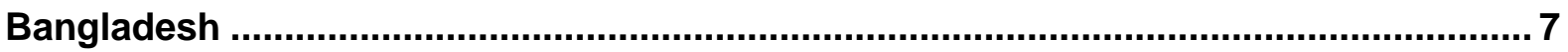

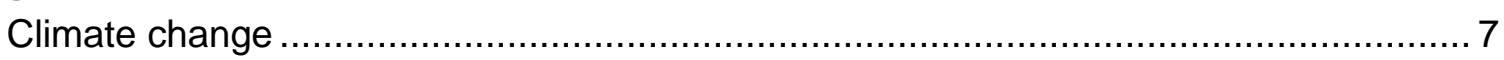

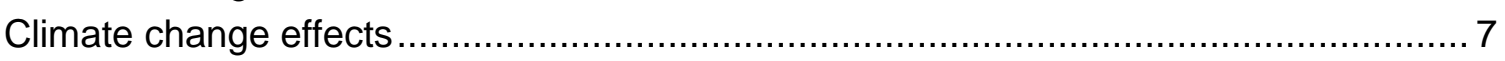

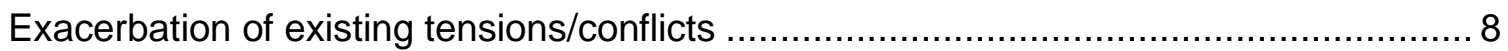

Guarding civic space and including all voices..................................................... 10

Freedom of expression and media freedom ......................................................... 10

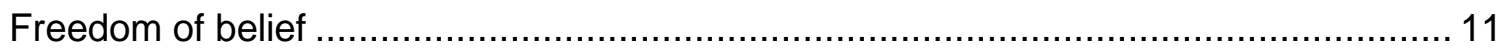

Civil society freedom and under-represented groups.......................................... 12

India

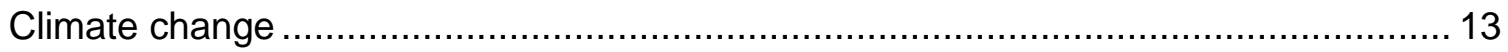

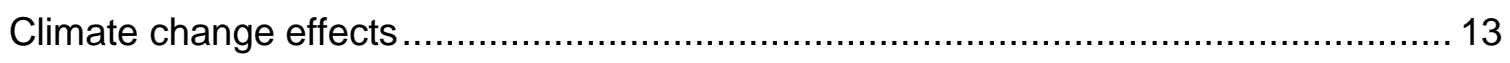

Exacerbation of existing tensions/conflict .............................................................. 13

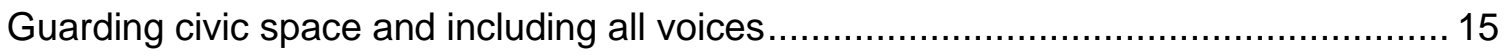

Freedom of expression and media freedom ...................................................... 15

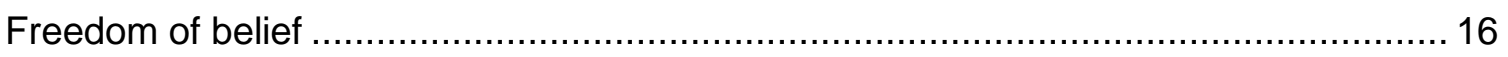

Civil society freedom and under-represented groups.............................................. 17

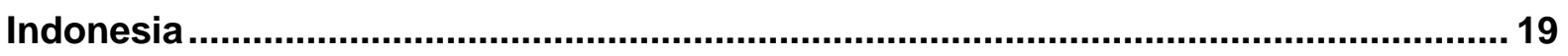

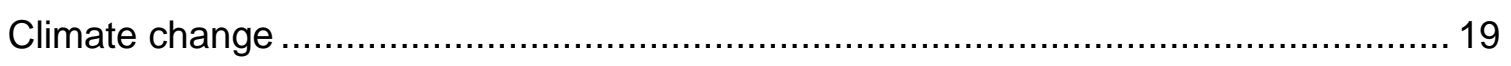

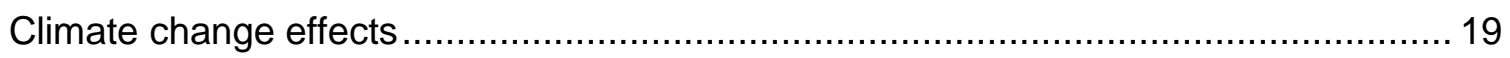

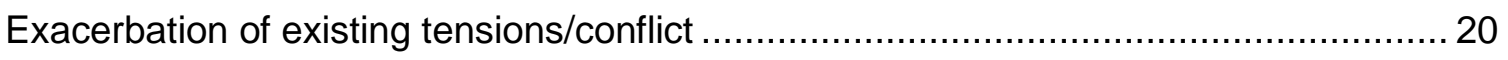

Guarding civic space and including all voices......................................................... 21

Freedom of expression and media freedom ........................................................... 21

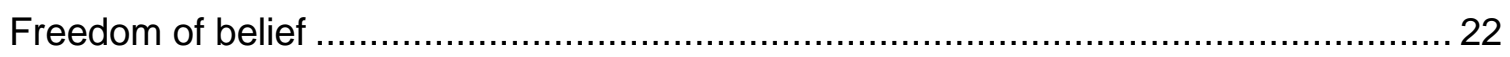

Civil society freedom and under-represented groups........................................... 23

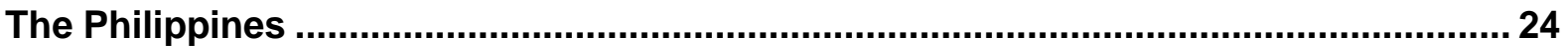

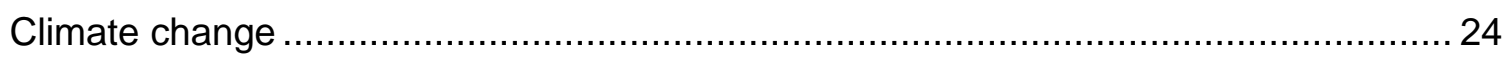

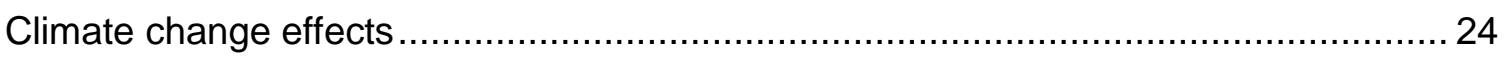

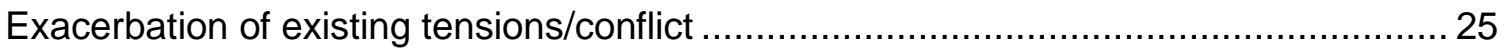

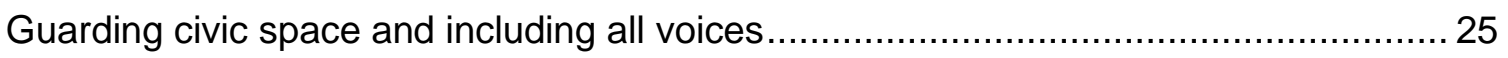




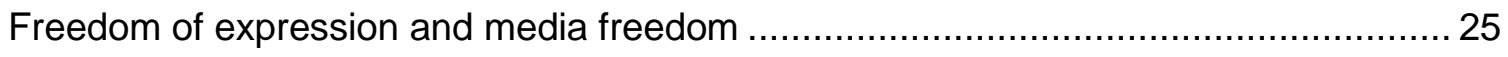

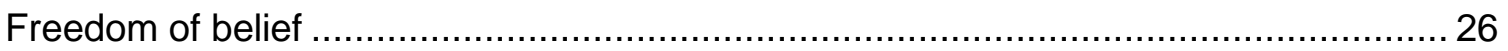

Civil society freedom and under-represented groups......................................... 27

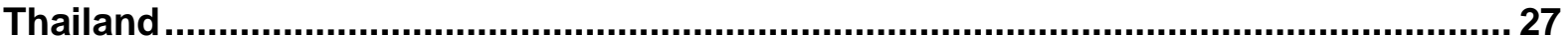

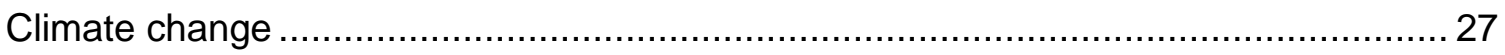

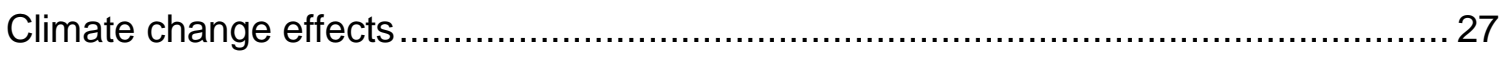

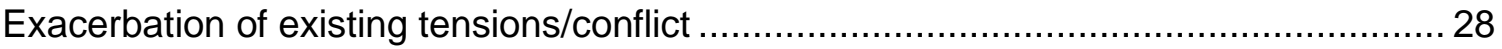

Guarding civic space and including all voices....................................................... 28

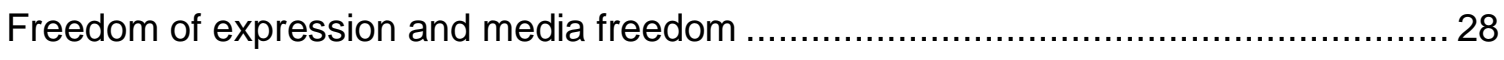

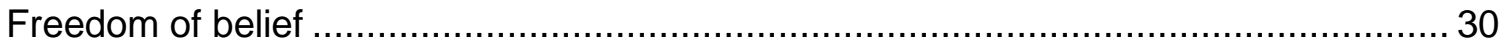

Civil society freedom and under-represented groups........................................... 30

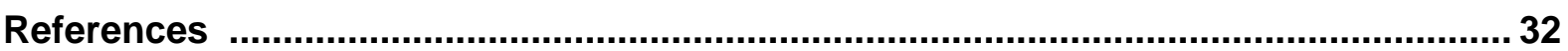




\section{Overview}

This report looks at trends in conflict and instability in the Indo-Pacific region, focusing on climate change effects and a number of civil liberties. The Indo-Pacific region is both highly vulnerable to the effects of climate change and already facing significant security risks and challenges, many of which will be exacerbated by the impact of climate change. There are notable increases in resource-based conflicts, migration-induced violence and armed insurgencies. The countries reviewed all show worrying trends in terms of erosion of freedom of expression, media freedom, freedom of belief and civil society freedom. The situation in Bangladesh and India is particularly serious and is already fuelling violence and conflict.

This EIR largely draws on grey literature, as well as media articles, blogs and other such sources. Given the wide range of issues and countries covered in this report (see below), it should be considered as a 'broad brush' review - it does not go into each issue in-depth. The available evidence was sufficient for this purpose. Evidence on climate change effects was particularly strong. However, the literature was gender-blind to a considerable extent.

The two themes on which the EIR focuses are (i) climate change and (ii) guarding civil space and including all voices. While there is a general consensus in the literature that there is not a direct causal link between climate change effects and conflict, the former can, in conjunction with other factors, lead to/exacerbate conflict risks. Guarding civic space and including all voices encompasses a broad range of issues. This EIR looks at freedom of expression, media freedom, freedom of belief, civil society freedom and treatment of underrepresented groups. Trends indicating that these freedoms are being undermined could fuel conflict risk. Indeed, in many of the countries reviewed, the erosion of these rights is already leading to violence and conflict.

The EIR examines the above two themes in five Indo-Pacific countries: Bangladesh, India, Indonesia, the Philippines, and Thailand. These were chosen to give a broad range of situations and challenges/risks from the region. Note that this EIR is confined to an assessment of conflict risks and does not examine measures being taken by government or others to address these.

Key findings are given below for each country:

\section{Bangladesh}

Climate change and conflict: Located in a low-lying delta, Bangladesh is one of the countries most vulnerable to the effects of climate change, including river and coastal flooding and erosion, rising sea levels and more frequent, more intense severe weather events. These are leading to (amongst other effects) reduced crop yields, increased food insecurity, diminished water resources, biodiversity loss and loss of livelihoods. Climate change impacts could: contribute to environmental migration and resource-based conflicts; exacerbate driving factors for violent extremism and anti-Hindu violence; generate emigration to neighbouring Indian states leading to interethnic and communal conflict there; and rekindle armed insurgency among indigenous communities in the Chittagong Hill Tracts. The continued influx of huge numbers of Rohingya refugees into the Cox's Bazar region of Bangladesh is already and will continue to accelerate environmental degradation there and could lead to ethnic conflict. 
Guarding civic space and including all voices: There are serious restrictions on freedom of expression and the media, in particular with regards to criticism of the Government. Moves such as arrests, physical assault and forcible disappearances have led to a high degree of self-censorship. Since 2011 Islam is the state religion in Bangladesh and minorities' freedom of religion has been eroded. Violent extremism is on the rise, with numerous (often brutal) attacks, particularly on secularists. The Government response has been inadequate, failing to provide protection or justice. Civil society groups (especially human rights groups) have been hit by many of the same restrictions affecting the media, notably through control of foreign funding. Ethnic and religious minorities, and the LGBT+ community, face some discrimination in law, as well as societal discrimination and harassment.

\section{India}

Climate change: India faces numerous climate-related hazards and is predicted to experience increased flooding from sea-level rise and extreme precipitation events, as well as increased severity of drought and heatwaves. These effects are causing degradation of agricultural lands, increased water stress, rising mortality and morbidity, and loss of biodiversity and livelihoods, with rural areas particularly negatively impacted. Climate change impacts could: contribute to resource-based conflicts and increased urban violence, including between religious and ethnic communities; contribute to the immigration of Bangladeshis into north-eastern states and Assam, igniting/reviving separatist movements; deepen local alienation and resentment towards the Indian government in Kashmir, and exacerbate insurgent and/or extremist violence in the state; accentuate interstate disputes over river water sharing, and exacerbate tensions between India and Pakistan over sharing of Indus River system waters, and between India and China over dam construction.

Guarding civic space and including all voices: India has seen a marked erosion in freedom of expression and media freedom, through a combination of legislative provisions, government actions (e.g., arrests) and harassment by Hindu nationalist groups. These have led to a high degree of self-censorship on the part of the media. While officially a secular democracy, the rise of Hindu nationalism - particularly since the 2014 election of Prime Minister Narendra Modi - has prompted many attacks on religious minorities, notably over cow slaughter and religious conversion. The Government has not only failed to protect those targeted, but fostered an environment in which hate speech and violence against minorities (especially Muslims) flourishes. Civil society groups, especially rights groups, are targeted by the Government, notably through restrictions on foreign funding and (mis)use of counterterrorism legislation. The position of Scheduled Castes (Dalits) and Scheduled Tribes in India remains difficult, with many facing discrimination and violence. Muslims have been most marginalised under the Modi government: in Assam, nearly two million Muslims were effectively rendered stateless, while the special autonomy of Indian-Administered Kashmir was revoked amid a massive security crackdown in the state.

\section{Indonesia}

Climate change: Indonesia is the world's largest archipelagic state, the world's fourth most populous country, and is highly vulnerable to sea-level rise as well as other climate changerelated disasters including forest and land fires, landslides, storms, and drought. Climate change impacts include reduced agricultural productivity and increased food insecurity, increased water stress, erosion of coastlines, increased forest fires, and biodiversity loss all leading to loss of livelihoods. Jakarta, one of the most densely populated cities in the 
world, is especially vulnerable. The only current armed challenges to the authority of the state in Indonesia come from a low-level separatist movement in Papua, and sporadic attacks from radical Islamist militants. There is also low-level local violence over resources and community rights. Climate change effects - with loss of land and displaced people - can be expected to intensify local clashes. Similarly, in-migration and exploitation of local resources by outsiders could fuel the Papua insurgency. In the context of climate change and conflict, it is worth noting that illegal logging and deforestation - rife in Indonesia contributes to both.

Guarding civic space and including all voices: Various laws against blasphemy, defamation, and certain other forms of speech are used to inhibit freedom of expression in Indonesia, particularly on sensitive topics such as criticism of the Government and the President. Media freedom is similarly hampered through legal and regulatory restrictions. Journalists covering sensitive subjects face harassment, threats and even physical assault and violence. Indonesia is overwhelmingly Muslim-majority, and religious minorities face restrictions (e.g., in setting up places of worship), discrimination and even violence, with the Government failing to protect them. Anti-blasphemy laws are another tool to target minorities, and use of these is growing. Non-governmental organisations (NGOs) are subject to government monitoring and interference. Marginalised ethnic groups include Papuans and, to a lesser extent, ethnic Chinese. LGBT+ people also suffer from widespread discrimination.

\section{The Philippines}

Climate change: The Philippines is comprised of over 7,000 islands, many low-lying and lacking natural barriers to the sea, and is in the world's most cyclone-prone region - some of the factors making it highly vulnerable to climate change effects such as sea-level rise. The impacts of these include crop loss/failure, rising food prices and food imports, water shortages, damage to coastal ecosystems and loss of livelihoods, and widespread infrastructure damage. The urban poor are especially vulnerable. The Philippines has two long-running insurgencies - by a number of Moro nationalist/separatist groups and by the communist New People's Army - as well as Islamist violent extremism. Climate change effects can be expected to exacerbate conflict. For example, drought and reduced agricultural productivity in Mindanao is leading to food insecurity and increased poverty, which is likely to exacerbate anti-government sentiment in the area, and drive support for separatist/violent extremist groups, especially among youth.

Guarding civic space and including all voices: The Philippines has been described as one of the most dangerous places in the world for journalists, and President Duterte's hostile rhetoric toward the media exacerbates this. His government has been overt in its suppression of the media. Journalists have been attacked, and 15 murdered under his administration, but the authorities make little effort to find those responsible or to protect journalists. The Government has also taken steps to curb civil society freedom, targeting both individual activists and organisations. Environmental and land rights activists are at particular risk, as well as critics of the President and government. The Philippines is a strongly Catholic country and, while there are no major issues with freedom of belief, LGBT+ people face discrimination and legal restrictions, including in employment, education, and other services. 


\section{Thailand}

Climate change: Thailand sits in the Mekong Delta plain and is ranked $8^{\text {th }}$ in the Global Climate Risk Index for long-term risk. Among the main climate change effects in the country are flooding, sea-level rise, saltwater intrusion and droughts. These will have a devastating impact on Thailand's tourism sector, which accounts for $12 \%$ of its GDP, as well as agriculture (accounting for around $50 \%$ of employment and $10 \%$ of GDP) and trade, while millions will be displaced. Climate change effects have also damaged ecosystems and livelihoods that depend on them. Thailand's capital city, Bangkok, is especially vulnerable. Thailand has been facing a hot-cold armed insurgency for many decades in southern provinces which have large Malay Muslim populations. The rise of 'extremist' Buddhism in the country is a factor. The literature does not refer to climate change effects influencing or exacerbating these specific conflicts/tensions, but it does assert that deteriorating environmental conditions could exacerbate existing social issues such as political unrest, poor economic conditions, food insecurity, inequality and poverty, and cause widespread destruction of livelihoods. These, in turn, could trigger clashes between different communities and wider conflict.

Guarding civic space and including all voices: There are significant restrictions on freedom of expression in Thailand despite the country's transition from military to semicivilian rule in July 2019. Various laws are used to target, among others, opposition politicians, academics, and activists. Two further significant restrictions on freedom of expression in Thailand are in relation to the monarch, and to Buddhism, both of which are punishable by law. Media freedom is curbed in Thailand using many of the same legal instruments. Civil society groups focused on defending human rights and freedom of expression, and promoting democracy, continue to face restrictions, criminalisation and prosecution by the state. As in the Philippines, land rights and environmental activists risk serious and even deadly violence in Thailand. There is widespread discrimination against LGBT+ people, by families and society, employers, and the authorities. Also marginalised in Thailand are indigenous hill communities in the north of the country, with many lacking formal citizenship, which renders them ineligible to vote, own land, attend state schools, or receive protection under labour laws. 


\section{Themes in relation to conflict and stability}

\section{Climate change}

\section{Links between climate change effects and conflict}

There is scientific consensus that climate change is real and is happening. According to the Intergovernmental Panel on Climate Change (IPCC) the warming of the climate system is unequivocal (van Baalen \& Mobjork, 2018: 1). However, on whether this is leading to violent conflict, the consensus in the literature is that there is not a direct causal link between climate change and conflict. Conflict situations and drivers of conflict are highly complex: 'Sequences of events leading to outbreaks of violence are always multifactorial and complex and it is usually not possible to identify single triggering factors' (Sida, 2018: 24). This is echoed in a very recent evidence review on climate change, conflict and fragility: 'The emerging consensus is that climatic factors can be just one of many drivers of conflict. Others are generally present, including very low economic development and social and political instability' (Peters et al, 2020: 7).

However, there could be indirect links as climate change effects exacerbate conflict risks: 'Climate change may exacerbate existing or create new socioeconomic stresses such as loss of arable land, resource scarcities, forced migration and weakening institutions, all of which could make a violent escalation of inter- and intrastate conflicts more likely' (Huntjens \& Nachbar, 2015: 13). There are several mechanisms by which climate change effects could lead to/exacerbate conflict risks (Sida, 2018; Froese \& Schilling, 2019):

- Diminished access to resources and increased competition over resources - as climate change causes a reduction in the availability of water, or usable land, pressure on natural resources increases and competition could lead to instability and conflict.

- Food insecurity - as food production is reduced and food prices increase, this could lead to social unrest and conflict.

- Extreme weather events causing economic shocks and livelihood insecurity - more frequent/severe storms, floods, drought, longer periods of extreme heat, etc. will cause destruction of physical infrastructure and assets and loss of livelihoods, with knock-on effects that could lead to conflict.

- Environmental migration - one effect could be large-scale displacement of people ${ }^{1}$ (e.g., from rural to urban areas, global south to global north), which places added strain on destination areas (on services, competition for natural resources) and could potentially destabilise them (e.g., conflict between migrant pastoralists and local farmers over land use).

- Sea-level rise and coastal degradation - again, one likely effect of this would be migration to inland/higher regions, potentially causing tension and conflict there.

- Reduced economic growth undermines government capacity - higher unemployment, higher taxes, reduced government revenue, increased oil prices and other effects indirectly caused by climate change could weaken governments' ability to provide services and create jobs, potentially creating conditions for extremism, crime and/or social breakdown.

${ }^{1}$ Similarly, although a direct causal relationship between climate change and migration is not generally supported in the literature, there is growing recognition of climate change as a contributing and exacerbating factor in migration. 
- Increased recruitment to armed groups - loss of economic opportunities and livelihoods because of climate change effects could drive desperate people into the hands of armed groups.

- Unintended effects of climate policies - E.g., when local communities are denied access to forests as part of REDD+ (Reducing Emissions from Deforestation and Forest Degradation) initiatives; local opposition to wind parks because these require land and on aesthetic grounds.

\section{Climate change effects in the Indo-Pacific}

The Indo-Pacific region is highly vulnerable to the effects of climate change and climate change-driven hazards including extreme weather (rain and heat) events such as cyclones, floods and droughts; sea-level rise; and acidifying oceans (IMCCS, 2020). Southeast Asia has, for example, one of the longest coastlines in the world, leaving it highly exposed to extreme weather events and sea-level rise which would affect major coastal cities such as Jakarta, Manila, Bangkok and Ho Chi Minh City (Nordqvist \& Krampe, 2018). From 19702018, approximately 1.1 million people were killed in storms, floods and other disasters (excluding earthquakes/tsunamis) in the Indo-Asia Pacific, and people in the region are five times more likely to be affected by natural disasters than those elsewhere (IMCCS, 2020: 7). Almost half of the 281 natural disaster events that occurred in 2018 were in the Asia-Pacific region, including eight out of the ten deadliest (IMCCS, 2020: 7).

These effects of climate change are taking place in a context of already significant security risks and challenges: growing geostrategic competition such as maritime boundary disputes and military build-up in contested zones of the South China Sea, expanding military capabilities across many countries; ongoing conflicts related to separatist movements and transnational violent extremist organisations, as well as piracy and serious organised crime (IMCCS, 2020). The International Military Council on Climate Change and Security (IMCCS) (2020: 5) warns that in the Indo-Asia Pacific adverse climate change impacts 'can seriously complicate these existing security vulnerabilities - eroding coping capacities, increasing grievances and worsening underlying tensions and fragilities'. Fetzek and McGinn (2020) stress the need to consider climate security consequences 'with a broad aperture, including how they affect current and future drivers of fragility and instability', and to coordinate comprehensive responses and shift to a more preventive posture.

\section{Guarding civic space and including all voices}

The above - 'guarding civic space' and 'including all voices' - are broad terms used by the Open Government Partnership (OGP). While the full range of issues under these can be very wide, this EIR focuses on freedom of expression media freedom, freedom of belief, civil society freedom, and treatment of under-represented groups. Other issues such as political liberties and gender equality, which could have fallen under the term, are not considered in this EIR because of time and space constraints.

This review looks at how these issues are handled in the five countries under consideration, to what extent rights to freedom of speech, etc. are respected, and the ways in which these are fuelling/exacerbating violence and conflict. Given the scope of issues (rights) being considered in the five countries, the review does not attempt to provide a comprehensive assessment of each issue in each country, but rather focuses on the most significant developments in terms of stability and conflict. 
While the EIR makes connections between climate change effects/impact and conflict risk in each country, for the theme of 'guarding civic space and including all voices' it only describes the situation and challenges - the way in which these developments are already directly/indirectly contributing to violence and conflict, or have the potential to do so, is implicit in those descriptions.

\section{Bangladesh}

\section{Climate change}

\section{Climate change effects}

Bangladesh is located in a low-lying delta (two-thirds of the country sits less than $5 \mathrm{~m}$ above sea level [USAID, 2018: 2]) which serves as the drain for several major river systems - the Brahmaputra, Ganges and Meghna, as well as Himalayan glacial melt and the area's annual monsoon rains (Newman, 2014). These factors contribute to make it one of the most vulnerable countries in the world to the effects of climate change: it ranks seventh on the Global Climate Risk Index 2020 (IMCCS, 2020: 32). In Bangladesh, climate change is leading to rising temperatures, river and coastal flooding and erosion, rising sea levels, increasing levels of salinity, and more frequent, more intense severe weather events (BIISS \& Saferworld, 2009: 7). Bangladesh is hit by a tropical cyclone, on average, once every three years (USAID, 2018: 1). Its situation is made worse by the fact that it is the world's eighthmost populous country with a population of over 165 million, and already has high levels of poverty - one in three people live in poverty (USAID, 2018: 1).

Key climate change impacts in Bangladesh include (USAID, 2018: 1-3):

- Agriculture and food security - reduced crop yields, fisheries and livestock losses, and increased food insecurity. The impacts of climate change are expected to decrease agricultural GDP by $3.1 \%$ each year, which equates to an overall loss in added value of USD 36 billion between 2005 and 2050. Rice production - a key source of nutrition - is expected to drop by $8 \%$ by 2050 .

- Water resources - decreased potable water supplies, changes to river flows and decreased irrigation water. Extreme climate events such as flooding, drought, sealevel rise, and cyclones are likely to significantly impact the functionality and accessibility of water supply and sanitation infrastructure. Millions living in the country's vast floodplains, coastal areas and delta will be affected.

- Health - increased health stress, higher prevalence of infectious diseases (including cholera, diarrhoea, malaria and dengue), injury and death from cyclones and floods. Healthcare service delivery will also be negatively affected.

- Ecosystems - biodiversity loss, loss of livelihoods and reduced natural flood protection. Natural resources provide livelihoods for over $75 \%$ of Bangladeshis, so ecosystems are critical. The Sundarbans, the largest continuous mangrove forest in the world (and a large source of carbon sequestration), could be inundated by a potential $45 \mathrm{~cm}$ rise in sea level by 2050 , reducing biodiversity and removing an important source of natural protection against high strong storm and cyclone winds, as well as storm surges and coastal flooding.

- Energy - increased demand for energy, damaged energy infrastructure and decreased hydropower capability. The combination of these is likely to lead to higher energy prices, affecting access for the poor. 
More than 5 million Bangladeshis live in areas that are very vulnerable to cyclones and storm surges and every year, between $30 \%$ and $70 \%$ of the country is flooded, placing pressure on land availability, agriculture, and water security and straining development (Blondel, 2012: 42).

Dhaka, the capital and only megacity in the country, will continue to be acutely affected by climate change (IMCCS, 2020: 32). It is exposed to excessive rainfall, flooding, cyclones, and heat and cold waves. These environmental stressors combine with non-climatic factors such as extreme population density, poverty, rural-to-urban migration, uncoordinated urbanisation and lack of basic public services to increase exposure and vulnerability (IMCCS, 2020: 32-33). Dhaka has already experienced a population explosion due to migration, much of it due to environmental factors, swelling from 4 million to 15 million within a few years - the city is forecast to hold an additional 25 million people by 2050 (Newman, 2014). Dhaka is ranked the second least liveable city in the world for its severe overcrowding - 'migrants far outstrip the city's ability to accommodate them' (Newman, 2014).

\section{Exacerbation of existing tensions/conflicts}

Bangladesh faces a number of significant security challenges, including long-standing hostility between the two main political parties leading to political violence, a rise in violent extremism, and the Rohingya refugee crisis (Herbert, 2019a). Climate change effects could fuel these, as well as localised clashes over land and other resources.

Resource-based conflicts: In 2009, a study based on extensive fieldwork in both source areas of environmental migration (those particularly vulnerable to climate change) and destination areas (for migrants leaving those source areas) in Bangladesh, looked at how climate change and security issues are interlinked. In source areas, it found that climate change effects were driving increased tension, crime and violence as livelihoods broke down and competition for resources intensified (BIISS \& Saferworld, 2009: ii). Climate changeinfluenced security issues in source areas included: tension over land, with increased competition for access to and control of land for farming; tension over property, as thefts (e.g., of cattle, household goods) increased in the wake of natural disasters such as floods; tension over water resources; and increased female insecurity and sexual violence. In destination areas, the study identified three main triggers of conflict (BIISS \& Saferworld, 2009: iii):

- Disputes over land - High levels of physical insecurity and conflict were reported in destination areas as a result of competition for land. There is particularly fierce competition for government-owned khas land ${ }^{2}$, which has led to violence in some cases. In one area, local gangs were restricting access to land and demanding money for rent. There have also been clashes in response to attempts by vested interests and landowners to grab land and/or forcibly evict migrants.

- Competition for employment - Migrants add to the labour pool, increasing competition for jobs. Migrants face a double insecurity: not only is it hard for them to find employment, but they also face reprisals from existing residents who blame them for unemployment and falling wages. This has led to migrants being harassed and attacked by local people.

\footnotetext{
${ }^{2}$ Khas land refers to state land which is 'free' and available for distribution to the landless (BIIS \& Saferworld, 2009: 19).
} 
- Competition for access to water - As in source areas, there is increasing competition for water. This leads to clashes between groups and forces many people to travel long distances to find water.

Violent extremism: The rise in violent extremism in Bangladesh, particularly since 2013, is driven by several factors, including the long-standing rivalry between the Awami League (AL) party and the Bangladesh Nationalist Party (BNP), weak governance, rising conservatism within Bangladeshi society and regional/international influences (Herbert, 2019a). Also significant are socioeconomic factors: a young population with high rates of youth unemployment, high levels of poverty and inequality (despite sustained economic growth in recent years) and rapid urbanisation (as noted above) (Herbert, 2019a). All these factors are likely to be exacerbated by the effects of climate change - in turn, potentially fuelling violent extremism in the country.

Anti-Hindu violence: Climate change effects are already leading to increased targeting of the country's minority Hindu population. Bangladeshi Hindus were targeted in a two-month-long spate of attacks between December 2013 and February 2014. While the immediate causes were anger by Islamic extremists over a contested election and war crimes tribunal, poverty and resource scarcity were major factors - victims noted that some attackers were mostly interested in grabbing Hindu land and property (Newman, 2014). Such incidents are likely to increase under the ongoing negative impacts of climate change. One army officer deployed to Rwanda after the 1994 genocide warned: 'I can see a similarity about potential threats in Bangladesh like Rwanda...there is an ominous sign of potential outbursts anytime' (cited in Newman, 2014).

India: Climate change effects could fuel emigration motivated by a quest for arable farmland and livelihoods across the border into India, specifically into West Bengal, Tripura and Assam states (Newman, 2014). Large-scale immigration sparked interethnic conflict in Assam in the early 1980s; in 1983, Assamese militants massacred several thousand Bengalis in a single day, and there was more bloodshed in 2012 (Newman, 2014). India has responded to migration issues with Bangladesh by erecting a barbed-wire fence along their shared border, with the stated goal of keeping out Islamic militants, illegal smuggling, and trafficking (Blondel, 2012: 42). However, the fence itself has become a source of tension with suspicions, fears and accusations from both sides and reports of several hundred people killed by border security guards (Blondel, 2012: 43; Herbert, 2019a: 20). At the same time, the Indian government has passed a law allowing Bangladeshi Hindus - but not Muslims to migrate to India (see India below). This increases the chances of clashes along ethnic lines between locals and migrants in Indian states bordering Bangladesh, and fuels intercommunal tension in both countries.

Chittagong Hill Tracts: The increase in extreme weather events in coastal regions could also lead to increased migration to the Chittagong Hill Tracts (CHT) region of the country. The $\mathrm{CHT}$ region has already seen conflict between indigenous communities in the area and Bengali settlers, relocated there by the Bangladesh government between 1979 and 1985 (Blondel, 2012: 42; Herbert, 2019a: 19). Local anger at the settlement of Bengalis led to calls for autonomy and armed insurgency; while the CHT Peace Accord in 1997 ended this, settlers and the Government are accused of not honouring their commitments (Blondel, 2012; Herbert, 2019a). The influx of climate refugees could reignite conflict in the region.

Rohingya crisis: Since 2016-17 Bangladesh has seen large numbers of Rohingya Muslims enter the country, fleeing violence in neighbouring Myanmar's Rakhine state. Most are concentrated in the Cox's Bazar district of Bangladesh, in the south of the country. As of 
January 2019, over 900,000 Rohingya refugees were residing in Ukhiya and Teknaf Upazilas of Cox's Bazar, most in 34 refugee camps (SEG, 2019: 10, cited in Idris, 2019: 3). The protracted presence of such large numbers of Rohingya refugees - chances of repatriation would appear to be negligible - places massive strain on local services, jobs and natural resources. 'The high number and prolonged residence of refugees increases the rate at which land and resources are used up, a process which accelerates environmental degradation and in turn leads to greater competition between natives and refugees for scarce land and resources' (Rahman, 2010: 237, as cited in Idris, 2017: 5). The Cox's Bazar region of Bangladesh is one of the poorest in the country, and traditional tourism revenue is being negatively impacted by the refugee influx (Cookson, 2017b, as cited in Idris, 2017: 5). There are already signs that the initial welcome extended to Rohingyas by Bangladeshis is dwindling, and tensions with the host community are growing. Malley (2018, as cited in Herbert, 2019a: 16) warns that the refugees' presence could play into communal conflict or aggravate political divisions, especially around elections.

\section{Guarding civic space and including all voices}

\section{Freedom of expression and media freedom}

Despite constitutional guarantees of freedom of expression, the Bangladesh authorities have imposed serious restrictions on this in order to suppress any criticism of the Government, as well as to limit religious freedom (see below). Various provisions, including under the Penal Code, have been used to target activists, writers, bloggers and journalists critical of the Government. Since 2013, hundreds of people - mostly opposition activists or critics of the Government and state agencies - have been 'forcibly disappeared' or have died in detention (Humanists International, 2020a: 5). This 'leads to self-censorship on some religious and political topics' (Humanists International, 2020a: 1).

There are considerable curbs on media freedom in Bangladesh. In October 2018, the Digital Security Act (DSA) was passed, which includes harsh provisions (e.g., allowing searches and arrests without warrant, criminalising various forms of speech) and has been used to penalise criticism of the Government (HRW, 2020a). According to the Bangladesh Editors' Council, the DSA effectively prohibits investigative journalism (HRW, 2020a). Journalists and media outlets face many forms of pressure: frequent lawsuits, harassment, closure of media agencies, arrest, and serious or deadly physical attacks (Freedom House, 2020a).

Numerous journalists were arrested in the run-up to the December 2018 national elections, and this has continued in their aftermath. During the campaign, reporters in the field were also targeted by political activists (notably supporters of the ruling Awami League party, and its student wing, the Chhatra League) (RSF, 2020a). According to Freedom House (2020a), 'a climate of impunity for attacks on media workers remains the norm'. Reporters Without Borders (RSF, 2020a) note that:

As a result, self-censorship has reached unprecedented levels because editors are reluctant to risk imprisonment or their media outlet's closure. Radical Islamist militants meanwhile harass and even murder journalists and bloggers who dare to defend an overly secular vision of society.

Bangladesh's ranking in the 2020 World Press Freedom Index was 151 (out of 180 countries), one place down from its 2019 ranking (RSF, 2020a).

There have been numerous arrests of journalists during the COVID-19 pandemic, as the Government tries to suppress criticism of its response to the crisis. As of May 2020, 16 
journalists had been arrested since the start of the pandemic (Article 19, 2020). Moreover, there have also been restrictions on public dissent: medical professionals have been told not to talk to the media; the Rapid Action Battalion (RAB) (an elite police unit) are monitoring social media and, by 10 April, had reportedly arrested ten people for spreading false information, and in May a circular was issued prohibiting all government employees from liking, sharing or commenting on social media posts critical of the Bangladeshi government (Article 19, 2020). Article 19 (2020) note that the crackdown on freedom of expression during the pandemic 'fits a wider pattern of serious restrictions on critical voices in Bangladesh, where there are currently dozens of journalists, bloggers and activists in prison for simply expressing their opinion'.

Internet censorship in Bangladesh has increased. Nearly 20,000 websites were blocked by the Government in February 2019 in what was described as an 'anti-pornography' sweep but included several popular blogging sites. In March 2019, access to Al-Jazeera's website was blocked following a report by the news agency citing allegations against the Prime Minister's security advisor (HRW, 2020a).

\section{Freedom of belief}

Despite Article 8 of the Constitution noting secularism as one of the four fundamental principles of the state, an amendment to the Constitution passed in 2011 established Islam as the state religion, while allowing equal status and equal right in the practice of other religions. However, according to the United States Commission on International Religious Freedom (USCIRF), '(a)midst the Bangladesh government's broader crackdown on civil rights, freedom of religion or belief continues to be impacted, especially for the countries' religious minorities - including Hindus, Buddhists, Christians and Ahmedi Muslims' (cited in Humanists International, 2020a: 1).

In recent years Bangladesh has seen a rise in violent religious extremism, targeted at secularists and religious minorities. Since January 2015, at least 40 individuals were murdered in such attacks, including secular writers, bloggers and publishers, and a Hindu priest (CEP, 2020: 8). The International Crisis Group notes that the attacks 'symbolise a new kind of extremist threat, aimed at silencing liberal and secular voices' (ICG, 2016: 7). The brutal way in which these killings were carried out, often using machetes, heightens the sense of fear they generate. In July 2016, there was a marked escalation in extremist violence with an assault on the Holey Bakery in Gulshan, Dhaka, in which Muslims and local Bangladeshi hostages were separated from non-Muslims and foreigners: 20 of the latter were killed (CEP, 2020: 1).

The authorities have failed to provide adequate protection to secular writers or to bring those responsible for the killings to justice. Indeed, 'the Government has frequently given in to pressure from Islamist parties, and continues to threaten atheists and others on charges of "hurting religious sentiments"' (Humanists International 2020a: 1). All of this is 'feeding a climate of fear and self-censorship' (Humanists International, 2020a: 3). Many secular writers are in hiding or have left Bangladesh to ensure their safety.

Communal violence is a growing problem in Bangladesh. Several Shia mosques and Ashura processions were attacked at the end of 2015. At least 101 people were reported to have been injured in violence against religious minorities in the first ten months of 2019; at least 65 temples, monasteries or statues were attacked, and 53 homes of religious minorities were attacked and set on fire (Humanists International, 2020a: 4). There have been a number of incidents in recent years in which violence against religious or other minorities appears to have been deliberately provoked using social media. In October 2019, for 
example, a Muslim mob attacked Hindu homes in Barisal after rumours circulated that a Hindu man posted blasphemous content on Facebook. Police later reported that the man's account had been hacked, but four people were shot and killed by police in response to the violence (Freedom House, 2020a).

\section{Civil society freedom and under-represented groups}

Civil society groups have been hit by similar restrictions to those affecting media organisations, and undermining freedom of expression and assembly. One mechanism for this is that the use of foreign funds must be cleared by the NGO Affairs Bureau, which can also approve or reject individual projects (Freedom House, 2020a). The 2016 Foreign Donations (Voluntary) Activities Regulation Act made it more difficult for NGOs to obtain foreign funds and gave officials broad authority to deregister NGOs.

Human rights groups have been especially targeted: 'Democracy, governance and human rights NGOs are regularly denied permission for proposed projects and are subject to harassment and surveillance' (Freedom House, 2020a). One prominent human rights NGO, Odhikar, had its foreign funds frozen, and its secretary was put on trial for contradicting the official number of casualties during a 2013 Islamist rally (ICG, 2016: 21). In 2019, the Government released a draft 'social welfare' law which would increase NGOs' reporting requirements and give the authorities broad powers to 'shutter groups they decide are not acting in the "public interest"' (Freedom House, 2020a). According to one analyst, the end result is that 'CSOs in Bangladesh are in a state of confusion: barring a handful, most stay silent regarding the widespread human rights abuses and choose to play safe on the multiple governance and rights deficits to avoid the wrath of the almighty authorities' (Alum, 2018).

Marginalised groups in Bangladesh include religious and ethnic minorities, as well as LGBT+ people. Ethnic and religious minorities face some discrimination under law as well as harassment and violation of their rights in practice. 'Indigenous people in the Chittagong Hill Tracts (CHT), religious minorities and other ethnic groups remain subject to physical attacks, property destruction, land grabs by Bengali settlers, and occasional abuses by security forces' (Freedom House, 2020a). Over 20 years after the CHT Peace Accord, the region remains under military occupation and indigenous rights activists face threats of arrest, enforced disappearance and violence. In April 2020, Michael Chakma, an indigenous rights activist, disappeared on his way to Dhaka. Despite a request in May from the High Court to the Home Ministry for a report on progress into the investigation of his disappearance, none has been provided (HRW, 2020a).

The LGBT+ community in Bangladesh faces hostility from wider society, as well as targeted attacks by extremists and harassment by the authorities. There is a criminal ban on samesex sexual acts. This is rarely enforced, but societal discrimination remains the norm and dozens of attacks on LBGT+ individuals are reported every year (Freedom House, 2020a). Seeking protection from the police is often not an option. As one LGBT+ campaigner explained: 'Police will beat you because you are gay. So why would you go to the police? It's a problem - we cannot approach the police with our problems' (Amnesty International, 2017: 24). After the 2016 murder of prominent LGBT+ activist Xulhaz Mannan, a number of LGBT+ individuals remain in exile for their own safety (Freedom House, 2020a). 


\section{India}

\section{Climate change}

\section{Climate change effects}

India faces numerous climate-related hazards. It is predicted to experience a 1.2-2.5 degree rise in temperature by 2050, increased flooding from sea-level rise and extreme precipitation events, and increased severity of drought and heatwaves (USAID, 2017b: 1). These are likely to have severe impacts (USAID, 2017b: 1-3):

- Agriculture - degradation of agricultural lands leading to reduced grain yields and milk production, and saltwater inundation and intrusion. Projections suggest this could lead to a $1.8 \%$ loss of GDP by 2050 .

- Water - reduced water quality, increased water stress and increased flood risk. India's most important river systems (Indus, Ganges and Brahmaputra) are fed by Himalayan glaciers, which are under threat from increased temperatures, severely impacting water availability for agricultural, domestic and industrial use. An estimated 12.6 million people live directly on land that is at risk from sea-level rise and nearly 171 million people depend on coastal ecosystems vulnerable to sea-level rise, cyclones and storm surges.

- Human health - increased heatwave- and heat stress-related mortality and morbidity, and diminished food security.

- Ecosystems - loss of biodiversity and increased coastal and forest degradation. Any change in forest cover, for example, would impact the 275 million people, including many indigenous communities, who are directly dependent on forests for their livelihoods.

Rural areas of India will be particularly affected: around $67 \%$ of the country's population and $80 \%$ of its poor live in rural areas; the agricultural sector employs some $60 \%$ of India's population (IMCCS, 2020: 14). Climate-sensitive rain-fed agriculture accounts for $60 \%$ of cultivated areas and $40 \%$ of national production (USAID, 2017b: 3).

\section{Exacerbation of existing tensions/conflict}

The IMCCS report (2020: 14) identifies three pathways by which climate change-induced threats to livelihoods and food insecurity in India could translate into violence:

- Lowered opportunity costs of joining rebel groups (including India's Maoist insurgency),

- increased opportunities for recruitment,

- accentuated and more widespread social grievances.

Instability and fragility related to economic and food security challenges can, in turn, decrease state capacities to address the underlying causes of these stressors, further increasing vulnerability and the risk of violence (IMCCS, 2020).

The effects and risks posed by climate change to India come on top of the many internal and international security challenges the country already faces, including sub-national insurgencies, ethnic, caste-based and communal conflict, and long-standing hostility with Pakistan as well as tension with China. These existing security challenges could be aggravated by the impacts of climate change. Inter-state population flows (conflict-induced migration) could manifest as ethnic or sectarian conflict. Security dynamics in some of India's most unstable regions intersect with climate-sensitive issues around water sharing 
and disaster risk and response. The IMCCS report (2020: 15-16) gives examples from around the country of how climate change effects could potentially fuel conflict:

- Urban areas - Urban violence in India has hitherto mainly taken the form of ethnic riots and violent protests, but climate-related events such as natural disasters, food price hikes or increased heat could drive greater urban violence in the future, including violence between religious and ethnic communities.

- Northeast - High climate vulnerability in Bangladesh could drive migration into neighbouring Indian states (Indian law grants citizenship to Bangladeshi Hindus). This could exacerbate tensions in northeast India and across the country given existing anti-migrant politics in those states, including from indigenous communities whose separatist movements are concerned over such a population influx. These dynamics could in turn deepen the alienation of minority populations across India.

- Kashmir - Climate change could drive increasing violence in the India-Pakistan standoff over Kashmir, which will see more floods, avalanches and other disasters as climate change increases glacier melt, extreme rainfall events and volatile river flows. Inadequate disaster response could deepen the Kashmiri population's alienation and resentment toward the Indian state, as was the case after major floods in 2014, when local residents alleged neglect by the Indian military forces responsible for relief efforts.

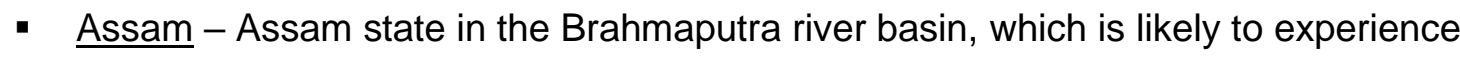
more climate-related flooding, has experienced major protests in response to the December 2019 Citizenship Amendment Act (giving Bangladeshi Hindus Indian citizenship). Although its separatist movement has waned, support for this cause combined with tensions with the central government - may increase in the context of more frequent and severe flooding and disasters.

- Interstate water disputes - Interstate disputes over river water sharing could also be accentuated under climate change, potentially leading to the kinds of violence, protests and riots seen in the Cauvery river dispute (over water sharing between Karnataka and Tamil Nadu), or contestations such as those over the Sutlej and Beas river waters that were a factor in Punjab's Sikh insurgency in the 1980s.

- Pakistan and China - Both India and Pakistan are dependent - the latter almost totally - on the Indus River system. There are already significant tensions over Indus waters due to factors such as dam construction by India and China's Belt and Road Initiative, which includes dams in Pakistan-administered Kashmir and Khyber Pakhtunkhwa. Climate impacts in the Himalayas and Indus river basin could worsen the tense India-Pakistan relationship, further stressing the Indus Water Treaty (which governs sharing of waters between the two countries) and necessitating dam designs that could lead to bad-faith actions, misunderstandings or manipulation of perceptions, e.g., around fears that India may intentionally release floodwaters or Pakistan may accuse India of this in the context of climate-driven flooding.

The above list highlights some key climate change-conflict hotspots and is by no means comprehensive, but it provides an indication of the scale of the climate change-security challenges facing India. Given existing tensions in South Asia and India's growing significance as a regional security actor, the IMCCS (2020: 16) warn: 'how successfully India manages climate-related challenges, and the impact they have on its domestic stability and national politics, will have a bearing on security not only in South Asia, but across the IndoAsia Pacific and globally'. 


\section{Guarding civic space and including all voices}

\section{Freedom of expression and media freedom}

The Indian Constitution guarantees the right to freedom of speech and expression but allows the Government to limit these in a number of situations, including in the interests of the sovereignty, integrity and security of the state, public order, and in relation to incitement to an offence (Kamdar, 2018). There are also several sections of the Penal Code that criminalise certain speech, e.g., Section 292 criminalises obscenity. The Government has used these various provisions to ban books and films, e.g. The Satanic Verses by Salman Rushdie, and India's Daughter, a 2015 documentary about the gang rape of a Delhi college student (Kamdar, 2018). In 2014, an RSS ${ }^{3}$ member was able to force Penguin India to withdraw a book about Hindus and pulp all copies in its possession, by bringing a series of civil and criminal actions against the book on the basis that it violated Section 295a of the Penal Code, which criminalises anything that 'outrages religious feelings of any class' of citizens (Kamdar, 2018).

Charges of sedition and defamation are also used in India to curb free speech and to intimidate government critics. A folk singer, students cheering at a cricket game, and the author Arundhati Roy are just some who have been charged with sedition (Kamdar, 2018). In October 2019, police in Bihar state filed a case of sedition against 49 people including well-known movie personalities, for writing an open letter to Prime Minister Modi expressing concerns over hate crimes and mob violence targeting minority communities (HRW, 2020b). The case was closed after widespread condemnation. Sections 499 and 500 of the Indian Penal Code criminalise defamation in terms so broad anyone can claim to be aggrieved by something said or written about them. 'This includes powerful Indian corporations, which do not hesitate to sue authors, journalists, or activists for defamation, backed up with claims for damages no author, publishing house, newspaper, or non-profit group can afford to pay' (Kamdar, 2018). As well as the threat of colossal punitive damages, filing a defamation suit against someone is a sure way to tie the person up with legal fees and court proceedings, potentially for years (Kamdar, 2018).

Physical intimidation can also prevent freedom of expression and speech. As Kamdar (2018) reports:

In January 2015, celebrated Tamil author Perumal Murugan 'declared literary suicide after being hounded by local chapters of right-wing Hindu groups affiliated with the ruling Bharatiya Janata Party (BJP) and the RSS that found passages in his novel One Part Woman offensive. After copies of his book were burnt by an angry mob and he'd received threatening phone calls, Murugan met with local authorities and agreed to apologize and withdraw copies of his book from sale'.

India's ranking in the 2020 World Press Freedom Index was 142 (out of 180 countries), two places down from its 2019 ranking (RSF, 2020b). While no journalists were murdered in 2019 (compared to six in 2018), 'there have been constant press freedom violations, including police violence against journalists, ambushes by political activists, and reprisals instigated by criminal groups or corrupt local officials' (RSF, 2020b). According to Reporters without Borders, since the overwhelming election victory of the BJP in spring 2019, pressure on the media to toe the Government's Hindu nationalist line has increased (RSF, 2020b):

${ }^{3}$ Rashtriya Swayamsevak Sangh (RSS), a Hindu nationalist paramilitary organisation. 
Those who espouse Hindutva, the ideology that gave rise to Hindu nationalism, are trying to purge all manifestations of "anti-national" thought from the national debate. The coordinated hate campaigns waged on social networks against journalists who dare to speak or write about subjects that annoy Hindutva followers are alarming and include calls for the journalists concerned to be murdered. The campaigns are particularly virulent when the targets are women.

As with freedom of expression, charges of sedition and defamation, undermining security and contempt-of-court charges are used to curb media freedom (Freedom House, 2020b). In addition, 'journalists risk harassment, death threats, and physical violence in the course of their work. Such attacks are rarely punished, and some have taken place with the complicity or active participation of police' (Freedom House, 2020b). This has contributed to selfcensorship on the part of the media. Press freedom is also undermined by close relationships between politicians, business executives and lobbyists, on the one hand, and leading media personalities and owners of media outlets, on the other (Freedom House, 2020b).

Freedom of expression and media freedom were totally curbed in Indian Administered Kashmir, following the Modi government's decision to rescind the state's autonomy (see below). Fixed-line and mobile internet connections were completely shut down for several months, 'making it virtually impossible for journalists to cover what was happening in what has become a vast open prison' (RSF, 2020b). [Slow speed 2G internet was restored after seven months. ${ }^{4}$ ]

\section{Freedom of belief}

The Constitution also guarantees freedom of religion, and India is officially a secular democracy, but the rise of Hindu nationalism has prompted religiously motivated attacks against religious minorities - especially since the election of Prime Minister Narendra Modi in 2014 (Freedom House, 2020b).

Legislation in several states (including Odisha, Madhya Pradesh, Chhattisgarh, Gujrat, Arunachal Pradesh and Himachal Pradesh) criminalises religious conversions that take place as a result of 'force' or 'allurement'; some states require government permission for conversion (Ochab, 2019; Freedom House, 2020b). Ochab (2019) notes that 'while conversions from Hinduism to other minority religions have been closely enforced with the threat of such conversions triggering criminal charges, conversion (including forced conversions) of non-Hindus to Hinduism continue to be practised with relative impunity'. According to the USCIRF (as cited in Ochab, 2019), 'These ceremonies are based on the view that all individuals born in India are Hindus by default, even if their communities have practised other faiths for several generations'.

Trading or killing cows for meat has become a particularly sensitive issue, with mob violence carried out against minorities - notably Muslims - by extremist Hindu groups affiliated with the ruling BJP. Between May 2015 and 2019, 50 people were killed and over 250 injured in such attacks (HRW, 2020b). 'Muslims were also beaten and forced to chant Hindu slogans' (HRW, 2020b). According to Freedom House (2020b) more than 120 cases of cow-related violence, including lynchings, have been reported since Modi came to power. The ruling BJP has been criticised for failing to mount an adequate response (Freedom House, 2020b).

\footnotetext{
${ }^{4}$ https://www.businessinsider.com/india-kashmir-internet-blackout-anniversary-i-lived-through-it-2020$8 ? \mathrm{r}=\mathrm{US} \& \mathrm{IR}=\mathrm{T}$
} 
'Police failed to properly investigate the crimes, stalled investigations, ignored procedures, and filed criminal cases against witnesses to harass and intimidate them' (HRW, 2020b). In August 2019, a Rajasthan court acquitted six suspects in the 2017 killing of a Muslim man, despite eyewitness accounts and video evidence of their complicity; the victim was posthumously charged with cow smuggling, though that case was dropped (Freedom House, 2020b).

There has also been a rise in other religiously motivated attacks, predominantly against religious minorities, notably Muslims. In 2017 alone, 111 people were killed and 2,384 injured in communal clashes (Ochab, 2019). Amnesty International (2019a) reports scores of hate crimes against Muslims and other religious groups, as well as others (e.g., caste-based crimes) taking place across the country, many carried out by vigilante groups and mobs. Moreover, 'the level of violence is expected to increase as perpetrators continue to enjoy impunity for their crimes' (Ochab, 2019). The Delhi police were accused of turning a blind eye to mobs who attacked Muslim neighbourhoods in February this year (AFP in Washington, 2020). In November 2019, the Supreme Court reached a long-awaited verdict in a case concerning a disputed religious site (Babri Mosque-Ayodhya Temple) in the state of Uttar Pradesh. While the judgment offered some accommodations to the minority Muslim community after finding that land for a mosque should be set aside elsewhere, it allowed construction of a Hindu temple to proceed at the site in question, where a mosque had stood for centuries until it was destroyed by Hindu extremists in 1992 (Freedom House, 2020b).

Earlier this year, the USCIRF issued its annual report condemning India's record on religious freedom: 'In 2019 religious freedom conditions in India experienced a drastic turn downward, with religious minorities under increasing assault' (cited in AFP in Washington, 2020). The Commission found that Narendra Modi's Hindu nationalist government 'allowed violence against minorities and their houses of worship to continue with impunity, and also engaged in and tolerated hate speech and incitement to violence' (cited in AFP in Washington, 2020). It pointed to comments by the Home Minister Amit Shah, who referred to mostly Muslim migrants as 'termites', and to a citizenship law that effectively rendered many Indian Muslims stateless (see below) as well as the repeal of autonomy in Indian-Administered Kashmir (AFP in Washington, 2020). The USCIRF called for India to be added to the list of 'countries of particular concern' (nine others on the list include Iran, Saudi Arabia, Myanmar and Pakistan) that would be subject to sanctions if they did not improve their record (AFP in Washington, 2020).

\section{Civil society freedom and under-represented groups}

Freedom House (2020b) note that a wide variety of NGOs operate in India, 'but some continue to face threats, legal harassment, excessive police force and occasionally lethal violence'. The Foreign Contributions Regulation Act (FCRA) has been used to restrict the functioning of certain groups, in particular those advocating human rights (HRW, 2020b). The FCRA allows the federal government to deny NGOs access to foreign funding: since 2015, nearly 15,000 associations have been deregistered under the FCRA (Freedom House, 2020b). In 2018, the offices of Greenpeace India and Amnesty International India were raided by government financial crimes units and their accounts were frozen (Freedom House, 2020b). In 2019, Amnesty International India was served with a 'show cause' notice for alleged violations of India's foreign exchange law, and in November that year the organisation's offices were raided by the Central Bureau of Investigation. Amnesty also reported being the target of an online smear campaign that some pro-government media outlets took part in (Freedom House, 2020b). 
Another legal tool used by the Government is the Unlawful Activities (Prevention) Act (UAPA) - a counterterrorism law. Rights groups are concerned about how the UAPA infringes on due process rights and has been misused to target religious minorities, critics of the Government and social activists (HRW, 2020b). In 2018, nine prominent human rights activists were imprisoned under the UAPA, accused of being members of a banned Maoist organisation and of inciting violent protests (HRW, 2020b). In the same case, in September 2019, a raid was conducted on the home of a Delhi University professor, who has been vocal on the rights of persons with disabilities and against caste discrimination (HRW, 2020b).

The position of Scheduled Castes (Dalits) and Scheduled Tribes in India remains difficult. The Constitution bars discrimination on the basis of caste, and laws set aside quotas in education and government jobs for historically underprivileged groups. Despite this, 'members of these castes and minorities face routine discrimination and violence, and the criminal justice system fails to provide equal protection to all marginalized groups' (Freedom House, 2020b). In parts of the country, especially rural areas, informal community councils issue edicts concerning social customs: these decisions can result in violence or persecution aimed at those perceived to have transgressed social norms, especially members of the scheduled castes (Freedom House, 2020b). In September 2019, the Supreme Court issued notices to authorities to examine caste-based exclusion at universities across India following a petition filed by mothers of two students - one a Dalit and the other from a tribal community - who committed suicide allegedly due to discrimination (HRW, 2020b). In February 2019, nearly 2 million people from tribal communities and forest-dwellers were placed at risk of forced displacement and loss of livelihoods after the Supreme Court ruled to evict all those who had claims rejected under the Forest Rights Act (HRW, 2020b).

While all minority groups in India face discrimination, it is Muslims who have been most marginalised under the Modi government. Two recent developments are particularly significant. In August 2019, the Assam government published a National Register of Citizens aimed at identifying Indian citizens and regular migrants following repeated protests and violence over irregular migration of ethnic Bengalis from Bangladesh (HRW, 2020b). The list excluded two million people, mostly Muslims, many of whom had lived in India for years, sometimes their entire lifetimes - the exclusion effectively rendered them stateless (Freedom House, 2020b; HRW, 2020b). 'Those excluded had allegedly failed to produce documentation that they or their ancestors resided in India before neighbouring Bangladesh became independent in 1971' (Freedom House, 2020b). In September 2019, India's Home Minister declared that the National Register of Citizens would be implemented across the country (HRW, 2020b).

In December 2019, the Indian parliament passed the Citizenship (Amendment) Act, amending the Citizenship Act to enable irregular migrants to acquire Indian citizenship through naturalisation and registration. However, it restricts the eligibility to only Hindus, Sikhs, Buddhists, Jains, Parsis and Christians from Afghanistan, Bangladesh and Pakistan who entered India on or before 31 December 2014 - Muslims are excluded (Amnesty International, 2019a). Freedom House (2020b) described it as a 'plainly discriminatory law ...to ensure citizenship for Bengali Hindus who were left stateless by the Assam register'.

The second significant development in relation to Muslims in India was the Government's sudden move, on 5 August 2019, to revoke the special autonomy of the country's only Muslim-majority state, Kashmir. Prior to doing so, in the first few days of August, the Government imposed a security lockdown in the state and deployed large numbers of 
additional troops. 'Thousands of Kashmiris were detained without charge, including former chief ministers, political leaders, opposition activists, lawyers and journalists. The internet and phones were shut down' (HRW, 2020b). While the Government claimed the measures were necessary to prevent loss of life, Human Rights Watch reported there were serious allegations of beatings and torture by security forces (HRW, 2020b). Some restrictions were lifted in November 2019, but hundreds remained in detention, mobile phone services and internet access were still limited, and opposition politicians, foreign diplomats and international journalists were blocked from making independent visits to Kashmir (HRW, 2020b).

One effect of the removal of Kashmir's special status is that non-Kashmiris will be able to buy property there, furthering what many see as the BJP's goal of changing the Muslimmajority demography of the state (AFP in Washington, 2020). The Government is also moving to break it into two smaller territories - Jammu and Kashmir - with a state legislature, and Buddhist-majority Ladakh which will be federally administered. There are fears that the erosion of Kashmiri autonomy will lead to a rise in radicalisation, as well as an influx of foreign militants (AFP in Washington, 2020).

Finally, the situation also remains difficult for LGBT+ people in India. Despite a Supreme Court ruling in 2018 that the use of Section 377 of the Indian Penal Code to ban same-sex sexual intercourse was unconstitutional, discrimination continues against LGBT+ people, including violence and harassment in some cases (Freedom House, 2020b). In June 2019, a criminal case was filed against Lawyers Collective, a group that provides legal aid, advocates for the rights of marginalised groups, and campaigns to end discrimination against LGBT+ people (HRW, 2020b). In November, the authorities sought the court's permission to arrest the organisation's founders for custodial interrogation despite their cooperation in the investigation (HRW, 2020b).

\section{Indonesia}

\section{Climate change}

\section{Climate change effects}

Indonesia is the world's largest archipelagic state, consisting of more than 17,500 islands with over $81,000 \mathrm{~km}$ of coastline. It is the world's fourth most populous country: 42 million people live on low-lying land less than 10m above sea level (USAID, 2017c: 1). Indonesia is highly vulnerable to sea-level rise: a $1 \mathrm{~m}$ rise in sea levels could inundate $4,050 \mathrm{~m}^{2}$ of coastal land and cause low-lying islands to disappear (Dunne, 2019). Indeed, 2,000 of the country's smaller islands are projected to be submerged by 2050 , and 5.9 million people are estimated to be affected by coastal flooding each year by 2100 (USAID, 2017c: 1). Indonesia is also vulnerable to other climate change-related disasters, notably forest and land fires, landslides, storms and drought.

Key climate change impacts in Indonesia include (USAID, 2017c: 1-3; MoFA, 2018):

- $\quad$ Agriculture and food security - Reduced rice productivity, increased damage to crops from flooding, drought and salinisation. Agriculture accounts for nearly $14 \%$ of GDP and the livelihoods of $42 \%$ of the working population, including more than half of poor households. Rice, a crop which is particularly sensitive to changes in temperature, is the staple food accounting for half of the calories consumed nationally. 
- Water resources - Reduced water supplies, decreased water quality, increased salinisation of coastal aquifers. In 2015, the Government declared 20 of the country's 34 provinces under severe drought.

- Human health - Increased mortalities and displacement from floods and landslides, increased incidence of vector- and waterborne diseases. Heat-related mortality, for example, is expected to increase from less than 1 per 100,000 to up to 25 per 100,000 by 2050 .

- Coasts and fisheries - Reefs and mangroves destroyed/damaged, increased erosion of coastlines, decreased marine fish populations.

- Forests and biodiversity - Increased risk of forest fires, new or expanded range of pests, loss of habitat for endemic and/or endangered species. In 2015, forest fires cost the country more than USD16 billion in losses.

Indonesia's megacities are particularly vulnerable to flash flooding, which can trigger devastating landslides. Jakarta, the capital, home to 10 million people and one of the most densely populated cities in the world, is also one of the most threatened due to environmental instability (Van der Vuurst \& Escobar, 2020: 1) - in particular sea-level rise. It has been described as the 'fastest sinking city' on Earth (Dunne, 2019; Henschke \& Utama, n.d.). Parts of the city have sunk by $4 \mathrm{~m}$ since levelling surveys began in 1978; the sinking makes it more vulnerable to flooding, tsunamis and intense coastal storms (Van der Vuurst \& Escobar, 2020: 2). Such is the scale of the threat facing Jakarta that the Indonesian government has announced it will be relocating the country's capital to the island of Borneo (Henschke \& Utama, n.d.). However, the move could lead to further deforestation and loss of vital biodiversity there.

Indonesia is vulnerable to climate change due to its high population density - especially in coastal areas, and strong dependence on natural resources for income generation and consumption (MoFA, 2018: 6). Deforestation has been happening on a massive scale, with land cleared and peats drained for palm oil production: from 2000-2015 the country lost an average of 498,000 hectares of forest each year (Dunne, 2019). Deforestation is a major driver of greenhouse gas emissions: Indonesia was the fourth highest emitter of greenhouse gases in 2015 (Dunne, 2019). The Asian Development Bank estimates that by 2100, the impacts of climate change will cost between $2.5-7 \%$ of GDP, and the poorest will bear the brunt of this burden ${ }^{5}$.

\section{Exacerbation of existing tensions/conflict}

There are currently no major violent conflicts in Indonesia: the only current armed challenges to the authority of the state come from a low-level separatist movement in Papua and radical Islamist militants, but in both cases violence is confined to sporadic attacks (Asia Foundation, 2017: 89). Nonetheless, there are a number of forms of low-level violence such as electoral and political violence, local violence over resources and community rights, urban crime and violence, and domestic and gender-based violence (Asia Foundation, 2017).

Papua was integrated into Indonesia in 1969 and has seen a low intensity but sustained armed insurrection ever since. Key sources of grievance - in addition to the original plebiscite for accession to Indonesia which Papuans see as illegitimate - include 'a sense of marginalization and disenfranchisement of indigenous Papuans, the perception that the exploitation of Papua's natural resources does not benefit locals, and the presence and poor track record of security forces' (Asia Foundation, 2017: 71). Counter-insurgency operations

${ }^{5}$ https://climateknowledgeportal.worldbank.org/country/Indonesia 
by the latter have been characterised by large-scale human rights violations, with hundreds of thousands of deaths and displaced people.

Clashes over land in Indonesia 'typically pit local communities against agribusiness companies or extractive industries granted concessions by the state, but they also map onto communal lines of opposition between different ethnic groups, or between indigenous populations and migrants' (Asia Foundation, 2017: 76). The security forces in Indonesia have been largely successful in dismantling Islamist terrorist cells, but extremist groups in the country retain strong links with transnational groups. In 2015, 500 Indonesians were fighting with the Islamic State in Irag and Syria (ISIS) with a special military unit, Katibah Nusantara, established for Malay Indonesian speakers (Asia Foundation, 2017: 70). There are worries that returned fighters could lead to bigger and better organised Islamist attacks at home in future (Asia Foundation, 2017).

Unlike other countries, the literature on Indonesia does not specifically identify ways in which climate change effects could exacerbate the above sources of conflict. However, given that clashes over land and natural resources are already a factor in low-level local violence, climate change effects - with loss of land and displaced people - can be expected to intensify such clashes. Similarly, climate change effects could lead to further in-migration in Papua and exploitation of local resources by outsiders - factors which are already drivers of the Papua insurgency.

One study looked specifically at the links between climate change, rice production and violent incidents in Indonesia over a 20-year period from 1993 to 2003 (Caruso et al, 2016). Rice was chosen because it is a staple food in both rural and urban areas of the country, and a source of income for a substantial proportion of households (average $46 \%$ of employment in agriculture between 1994 and 2003 - Caruso et al, 2016). The study looked at the links between climate change and violence via rice production in 14 provinces. Robust evidence found a close relationship between the increase in minimum temperature reached during the rice-growing season (which negatively affected rice production and per capita rice availability) and an increase in violence (Caruso et al, 2016). In the context of climate change and conflict, it is also worth noting that illegal logging and deforestation fuels both (Blondel, 2012).

\section{Guarding civic space and including all voices}

\section{Freedom of expression and media freedom}

According to Freedom House (2020c), laws against blasphemy, defamation, and certain other forms of speech can be used to inhibit freedom of expression in Indonesia, particularly on sensitive topics such as criticism of the Government and the President. The Electronic Information and Transactions (ITE) Law is frequently used in this regard. Amnesty International (2019b) found that 203 criminal investigations were initiated between October 2014 and March 2019 against those who expressed criticism of public officials, their spouses, or government institutions through electronic media, social media platforms, or during protests - based on charges of defamation, 'hoax dissemination' and 'incitement of enmity', all provisions under the ITE law. In September 2019, human rights lawyer Veronica Koman was charged with 'inciting hatred' for posts on social media relating to unrest in Papua (Hamid, 2019).

Authorities also use the Criminal Code and its makar ('rebellion') provisions, which criminalise acts - whether violent or not - committed with the intent to make part or all of 
Indonesia fall into the hands of the enemy or to secede; harm the President or Vice President; or overthrow the Government (Amnesty International, 2019b). Peaceful proindependence activists in Papua and Maluku were among those arrested, prosecuted and imprisoned using makar charges (Amnesty International, 2019b).

Hamid (2019) points to the increasingly prominent role of the police and their abuse of authority in defending governmental institutions, including the President. He cites data from Amnesty International that 241 individuals were criminalised for criticising authority figures of the Joko Widodo administration during the first term of his presidency (2014-19), including 82 cases involving people considered to have uttered 'hate speech' and 'insults' towards the President (Hamid, 2019). Moreover, 65 of the 82 cases involved social media - brought to light largely through police monitoring of cyber activities (Hamid, 2019).

According to Freedom House (2020c), civil servants are subject to stringent restrictions on online activity. In November 2019, the Government formed a task force to review 'radical' social media comments from civil servants, including speech believed to insult or criticise the official Pancasila ideology, the state motto, the constitution, or the Government. Civil servants are also prohibited from joining organisations deemed to insult the country's governing principles.

Media freedom in Indonesia is similarly hampered through legal and regulatory restrictions (Freedom House, 2020c). The 2008 ITE Law extended libel to online media, criminalising the distribution or accessibility of information or documents that are "contrary to the moral norms of Indonesia' or involve gambling, blackmail, or defamation (Freedom House, 2020c). Journalists covering sensitive subjects face harassment and threats, and sometimes also physical assault and violence - which in many cases goes unpunished (Humanists International, 2020b). In May 2019, at least seven journalists were assaulted by police and by demonstrators while covering a post-election protest in Jakarta that turned violent (Freedom House, 2020c). Another tool used by the authorities is cutting internet access (RSF, 2020c; Freedom House, 2020c).

Media reporting has been especially restricted in the provinces of Papua and West Papua, which have seen increasing unrest. Foreign journalists are not allowed to travel to the two provinces without special permission (Humanists International, 2020b). Violence against local journalists has grown, while 'foreign journalists and local fixers are liable to be arrested and prosecuted, both those who try to document the Indonesian military's abuses and those who just cover humanitarian issues' (RSF, 2020c). In late August 2019, the Government slowed internet speeds in Papua as major protests took place, limiting journalists' ability to report on events in the region (RSF, 2020c; Freedom House, 2020c). According to Reporters without Borders (RSF, 2020c), religious groups also threaten media freedom and many journalists say they censor themselves because of the threat from anti-blasphemy legislation.

\section{Freedom of belief}

Indonesia officially recognises six major religions (Islam, Catholicism, Protestantism, Buddhism, Confucianism and Hinduism), but does not accept atheism. Those leaving the 'religion' section on their identity card blank, or adherents of unrecognised faiths, often face discrimination (Freedom House, 2020c). There is persistent violence against Ahmedi and Shia communities, and, according to Freedom House (2020c), 'the central government continues to tolerate persecution of these groups'. National and local governments not only fail to protect religious minorities but exhibit bias in investigations and prosecutions (Freedom House, 2020c). 
Religious minorities face significant obstacles in setting up places of worship. A permit requires the signatures of 90 congregation members and 60 local residents of different faiths, as well as the approval of the local Interfaith Communication Forum (Harsono, 2020). Given that Indonesia is $88 \%$ Muslim, these forums are overwhelmingly Muslim majority, and are able to exert veto power over minority groups. Not only does this make it very difficult for the latter to establish new churches, temples, etc., but the 2006 regulation has also been used to shut down hundreds of churches as well as Ahmedi and Shiite mosques and shrines of local ethnic religions (Harsono, 2020).

Indonesia has anti-blasphemy legislation penalising those who 'distort' or 'misrepresent' recognised faiths. Humanists International (2020b) reports that there were 88 cases of blasphemy between 1988 and 2017. In 2016 a Buddhist woman was convicted and sentenced to one and a half years in jail for complaining about the decibel level of a call-toprayer (azan) at a mosque (HRW, 2020c). Following her complaint, mobs burned and ransacked at least 14 Buddhist temples, and as of October 2019 she was still in jail (Humanists International, 2020b: 4). Moreover, the Government is seeking to expand the scope of anti-blasphemy legislation to include, for example, the offence of 'persuading someone to be a non-believer' (HRW, 2020c; Humanists International, 2020b).

\section{Civil society freedom and under-represented groups}

NGOs in Indonesia are subject to government monitoring and interference (Freedom House, 2020c). A 2013 law requires all NGOs to register with the Government and submit to regular reviews of their activities. It also limits the type of activities they can undertake - they are barred from committing blasphemy or espousing ideas (e.g., atheism, communism) that conflict with the official Pancasila ideology (Freedom House, 2020c). Moreover, the Government can dissolve non-compliant NGOs without judicial oversight.

Marginalised ethnic groups include Papuans and, to a lesser extent, ethnic Chinese. Papuans face racial discrimination from both the wider public and the authorities (Freedom House, 2020c). In August 2019, police officers were filmed using racial slurs as they arrested a group of 43 Papuan students (Freedom House, 2020c). Papuan activists and supporters of the region's separatist movement are watched and frequently detained by the authorities. Ethnic Chinese make up approximately $1 \%$ of the population. Despite reputedly holding much of the country's wealth, they are still vulnerable to harassment (Freedom House, 2020c).

LGBT+ people in Indonesia suffer from widespread discrimination. Humanists International (2020b) reports that, 'LGBTQ+ rights in Indonesia are increasingly maligned both in society and by the Government despite there being no law against sexual minorities as such. An intensification of Islamist demands drives growing intolerance of LGBTQ+ rights'. Nahdlatul Ulama, Indonesia's largest Muslim organisation, has called for LGBT+ activism to be criminalised; this has driven activists underground and hampered groups seeking to provide services to LGBT+ people (Freedom House, 2020c). The authorities also target LGBT+ people with inflammatory and discriminatory rhetoric. 


\section{The Philippines}

\section{Climate change}

\section{Climate change effects}

The Philippines ranks second in the Global Climate Risk Index 2020 of the countries most affected by extreme weather events in 2018 and fourth on the countries most affected by climate change from 1999 to 2018 (Germanwatch, 2020: 6). This is due in large part to geography: the Philippines is located in the western Pacific Ocean, surrounded by naturally warm waters, and is comprised of over 7,000 islands, many low-lying and lacking natural barriers to the sea. It is in the world's most cyclone-prone region, averaging 19-20 cyclones each year, of which 7-9 make landfall (USAID, 2017a: 1). Climate change effects to which the country is highly vulnerable include sea-level rise, increased frequency and intensity of extreme weather events, rising temperatures and extreme rainfall (USAID, 2017a: 1). Sea levels in the Philippines are rising faster than the global average, increasing the hazard posed by storm surges and threatening permanent inundation of low-lying areas (USAID, 2017a: 1).

The impacts of these climate change effects are wide-ranging and significant (USAID, 2017a: 1):

- Agriculture - Crop loss/failure, soil erosion, increased pest infestations, rising food prices and food imports. From 2006-2013, the Philippines was struck by 75 disasters - mostly cyclones, tropical storms and floods - that caused USD3.8 billion in accumulated damage and losses to the agriculture sector. An estimated annual GDP loss of up to $2.2 \%$ is projected by 2100 due to climate impacts on agriculture.

- Water - Water shortages, degraded water quality, increased flood and landslide risk,

- Energy - Reduced energy production potential, increased demand for energy services. For example, hydropower production, which contributes $20 \%$ to the country's energy supply, is vulnerable to reduced water availability from climate change.

- Coastal ecosystems - Loss of coastal defence, marine habitat and biodiversity, reduced fish populations. More than $60 \%$ of the coastal population's livelihoods depend on marine resources, and coral reefs and mangroves are valued at USD2 billion and USD83 million per year, respectively, for their contributions to fishing, tourism and storm protection.

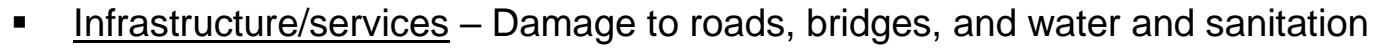
facilities. Rising sea levels threaten infrastructure and settlements in 25 cities located along the coastline.

- Human health - Loss of life and livelihoods, increased risk of vector-/waterborne disease (e.g., diarrhoea, dengue, malaria) and population displacement. Increases in malaria and dengue in the Philippines are positively correlated with changes in temperature.

The urban poor, many of whom live in temporary shelters, are most at risk, lacking the resources to prevent or mitigate the threat of coastal inundation and storm surge. The largest metropolitan area in the Philippines is Quezon City (Metro Manila) with approximately 2.9 million inhabitants (IMCCS, 2020: 34). Quezon City is particularly vulnerable to the effects of climate change, with the most pertinent challenge being the frequency and intensity of tropical storms, including excessive rainfall, cyclones, and typhoons, that lead to coastal floods (IMCCS, 2020: 34). The impact of these security risks is exacerbated by 
urbanisation, population density, and the fact that poverty and inequality remain significant challenges in the Philippines. The IMCCS (2020: 34) notes that in rural and coastal municipalities, natural hazards often have destructive socio-economic effects that cause a continuous cycle of poverty and inequity.

\section{Exacerbation of existing tensions/conflict}

Conflict has been a longstanding feature of the Philippines, with two long-running insurgencies - by a number of Moro nationalist/separatist groups in Mindanao and the Sulu Archipelago, and by the communist New People's Army (nationwide, but recently mainly in western Mindanao) - and a number of other types of conflict and violence. The latter include violent extremist groups such as Abu-Sayyaf, anti-drug violence by state actors and vigilantes, electoral violence, and local conflicts over resources and community rights (Herbert, 2019b). Both Central and Western Mindanao are Muslim-majority areas in the southern part of the Philippines; over 150,000 people are estimated to have been killed there in the past five decades (Barron, Engvall \& Morell, 2016, as cited in Herbert, 2019b: 5).

Drivers of conflict in the Philippines include poverty, lack of opportunities, land dispossession (indigenous Muslims to Christian migrant settlers) and religious and economic marginalisation. The Government's 'heavy handed' response to insurgencies/violent extremism (with widespread human rights violations) has exacerbated the situation. Also significant, particularly in the Mindanao/Sulu Archipelago region, are a lack of rule of law, governance weaknesses, clan politics, criminality, and violent extremist preaching/transnational links to violent extremist groups (Herbert, 2019b: 2-3).

Climate change effects in the Philippines can be expected to exacerbate conflict. For example, an El Niño-caused drought led to a demonstration by at least 6,000 farmers in 2016 where they demanded government subsidies; the violent police response killed three, and left hundreds injured (Asia Foundation, 2017: 151, as cited in Herbert, 2019b: 13). Similarly, climate change is causing drought and reduced agricultural productivity in Mindanao, leading to food insecurity and increased poverty in a part of the country where poverty levels are already high (two-fifths of the poor in the Philippines live in Mindanao Herbert, 2019b: 12). This is likely to fuel anti-government sentiment in the area and drive support for separatist/violent extremist groups, especially among youth.

Women are affected in different ways: 'Women are more disadvantaged and as such tend to farm in smaller plots, work shorter hours or limit farming to cash crops. Extreme climate events in conflict-prone agrarian communities appear to subject women to forced migration, increased discrimination, loss of customary rights to land, resource poverty and food insecurity' (Chandra, et al., 2017, as cited in Herbert, 2019b: 13).

\section{Guarding civic space and including all voices}

\section{Freedom of expression and media freedom}

Freedom of expression in the Philippines is looked at alongside civil society freedom below.

Reporters without Borders (RSF, 2020d) ranked the Philippines 134 out of 180 countries for press freedom in 2020, down two places from 2019. According to Freedom House (2020d) 'the Philippines remains one of the most dangerous places in the world for journalists, and the President's hostile rhetoric toward members of the media exacerbates an already perilous situation'. When sworn in as president in June 2016, Rodrigo Duterte warned: 'Just because you're a journalist, you are not exempted from assassination if you're a son of a 
bitch' (RSF, 2020d). His government has been overt in its suppression of the media. Freedom House (2020d) cited a coalition of media groups reporting that:

from June 30, 2016 to April 30, 2019, there were 128 documented attacks and threats against the press, including physical attacks; threats, including death threats and bomb threats; smearing journalists as conspiring against the Government; "redtagging," or alleging that targets harbour communist sympathies or connections in order to increase harassment against them; and DDoS attacks on alternative-media sites.

DDoS refers to distributed denial of service attacks that generate fake visits to websites and render them inaccessible (Amnesty International, 2019b). Amnesty International (2019b) cites media organisations saying at least 15 journalists had been killed in the Philippines in connection with their work under the Duterte administration since 2016.

The authorities make little effort to find those responsible, or to protect journalists. Indeed, Freedom House (2020d) assert that 'impunity remains the norm for violent crimes against activists and journalists'. In 2009, 58 people, including 32 journalists, were killed in Maguindanao in the southern Philippines. As of October 2020, of the 197 people charged with murder, 80 remained at large, 55 were acquitted and 28 were convicted of murder - this happened in December 2019, ten years after the massacre (Humanists International, 2020c; RSF, 2020d). Those at large include police officers and members of a notorious clan with political influence in the region (Humanists International, 2020c).

As well as intimidation and assaults, various laws are used to target journalists. These include Executive Order 608 which established a National Security Clearance System to protect classified information, and the Human Security Act which allows journalists to be wiretapped based on suspicion of involvement in terrorism (Freedom House, 2020d). Libel is a criminal offence, and libel cases have been used frequently to quiet criticism of public officials (Freedom House, 2020d). Journalists are regularly charged under cyber libel laws which are punishable by up to eight years in prison (HRW, 2020d).

The treatment of online news site Rappler exemplifies the Duterte government's attitude to media critics. Rappler has reported extensively on killings and other human rights violations in Duterte's 'war on drugs'. In 2018, the Government revoked Rappler's registration for violation of regulations that forbid foreign entities from exerting any control over domestic news outlets (Freedom House, 2020d). By February 2019, founder and editor-in-chief Maria Ressa had been arrested twice and had posted bail for 11 different charges including tax evasion, libel, cyber-libel and violations of the Securities and Exchange Commission regulations (Freedom House, 2020d). Amnesty International (2019b) reported that Ressa along with a former Rappler reporter and board members - faced at least ten politically motivated lawsuits.

The extent to which media freedom has been stifled in the Philippines is clear from a survey in which half of the journalists taking part agreed that 'it is dangerous to print or broadcast anything critical of the administration, even if it is the truth' (HRW, 2020d).

\section{Freedom of belief}

The Philippines is almost $80 \%$ Catholic, with large Muslim minorities in the south. The literature does not report any significant issues with regards to freedom of belief. 


\section{Civil society freedom and under-represented groups}

The Government has taken steps to curb civil society freedom, targeting both individual activists and organisations. According to Freedom House (2020d), 'Environmental and land rights activists operate at a particularly acute risk. The international environmental rights group Global Witness reported in its most recent statistics that 30 land and environmental defenders were killed in the Philippines in the year 2018 alone'. Global Witness asserted that in 2018 the Philippines became the most dangerous country in the world for land and environmental activists (HRW, 2020d).

Critics of the President and Government are also targeted. In July 2019, sedition charges were filed against Vice President Leni Robredo and 35 other people including priests and bishops, political opposition members, and human rights lawyers and activists, for allegedly participating in a plot to oust Duterte (HRW, 2020d). The charges are attributed by many to these people criticising Duterte's war on drugs and the widespread human rights violations by the authorities (HRW, 2020d). Senator Leila de Lima - one of the most outspoken critics of Duterte's anti-drugs war - was arrested in 2017 on charges of accepting money from drug dealers and was still in jail three years later; she is recognised as a prisoner of conscience by a number of international rights groups (Freedom House, 2020d).

With regards to civil society groups, in November 2018 the Securities and Exchange Commission issued a memorandum, ostensibly to protect non-profits from money laundering and terrorist financing abuse, mandating them to disclose past and present funding sources, and specify the projects and activities funded (Freedom House, 2020d). Rights groups criticised the memorandum as unnecessary government intrusion.

The Philippines is a strongly Catholic country - for example, it is the only place in the world, other than the Holy See, which does not allow divorce. As such, it is no surprise that LGBT+ people face discrimination and legal restrictions, including in employment, education and other services (Freedom House, 2020d). In 2017, the House of Representatives passed the Sexual Orientation and Gender Identity and Expression (SOGIE) Equality Bill, which would protect against discrimination on those grounds (Freedom House, 2020d). However, in 2019 the Senate failed to pass the bill. It has also not passed legislation recognising same-sex partnerships and extending benefits to same-sex couples (HRW, 2020d). President Duterte declined to certify the SOGIE Equality Bill as urgent and the Government said it would push for a broader law that would cover 'all forms' of discrimination (Amnesty International, 2019b).

\section{Thailand}

\section{Climate change}

\section{Climate change effects}

Thailand sits in the Mekong Delta plain and is ranked $8^{\text {th }}$ in the Global Climate Risk Index 2020 for long-term risk (covering the 20-year period from 1999 to 2018) to extreme weather events (German Watch, 2020: 9). Among the main climate change effects in the country are flooding, sea-level rise, saltwater intrusion and droughts. The current area in Thailand exposed to coastal flooding is projected to increase by $37 \%$ by 2100 (IMCCS, 2020: 19). This means 23 of its 64 beach regions could disappear under water, losing at best $46 \%$ and at worst $72 \%$ of their surface. This will have a devastating impact on Thailand's tourist sector, which accounts for 12\% of its GDP (IMCCS, 2020: 19). Other key sectors of the 
economy which will be hit include agriculture (accounting for around $50 \%$ of employment and $10 \%$ of GDP) and trade, while millions will be displaced (Kisner, 2008: 1). Saltwater intrusion has caused a significant decline in rice yields in the Upper Gulf of Thailand and contributed to vulnerability of mangrove forests (which act as a natural buffer to protect inland territories) and degraded coral reefs (Open Development Thailand, 2018). Climate change effects have also damaged ecosystems and livelihoods that depend on them.

Thailand's capital city, Bangkok, is especially vulnerable, ranking $7^{\text {th }}$ in cities most exposed to climate change impacts (IMCCS, 2020: 19). Its mean elevation is just $1 \mathrm{~m}$ above sea level; it has 20 flood-prone locations and four flood-sensitive districts (IMCCS, 2020: 35). Bangkok could lose $40 \%$ of its land by 2030 - indeed, new projections state that the entire city could be subject to coastal flooding as early as 2050 (IMCCS, 2020: 19). While significant flood protection projects are underway for Bangkok, including a flood protection wall, it remains vulnerable (IMCCS, 2020: 35). Bangkok is home to 15\% of the country's population and serves as the economic, political and social centre not only for Thailand, but for the greater Mekong region. Climate change effects in the city will therefore have devastating impacts on millions of people.

\section{Exacerbation of existing tensions/conflict}

Thailand has been facing a hot-cold armed insurgency for many decades in southern provinces, notably Patani as well as Narathiwat, Yala and the southernmost districts of Songkhla, all of which have large Malay Muslim populations. The insurgency reignited in 2004 , with some 15,000 violent incidents and 6,000 deaths ( $90 \%$ civilians) up to 2018 according to one estimate (Morch, 2018). While the southern insurgency has historic roots, the rise of 'extremist' Buddhism in the country is a factor. This rise is part of a regional trend, also seen in Myanmar and Sri Lanka. For example, in Thailand, it is manifested in demands to make Buddhism Thailand's official religion, as well as in attacks against Muslims (Hutt, 2016). There has also been periodic political unrest for many years, including in recent months demonstrations against the monarchy (Chachavalpongpun \& Kurlantzick, 2020).

The literature does not refer to climate change effects potentially influencing or exacerbating these specific conflicts/tensions, but it does assert that deteriorating environmental conditions could exacerbate existing social issues such as political unrest, poor economic conditions, food insecurity, inequality and poverty, and cause widespread destruction of livelihoods. These, in turn, could trigger clashes between different communities and wider conflict. The IMCCS (2020: 19) warn, for example, that 'the social and political consequences of the tourism loss could be devastating and politically disruptive across the region'.

\section{Guarding civic space and including all voices}

\section{Freedom of expression and media freedom}

There are significant restrictions on freedom of expression in Thailand despite the country's transition from military to semi-civilian rule in July 2019. According to Freedom House (2020e), 'anyone perceived as a critic of the military or monarchy remains at high risk of surveillance, arrest, imprisonment, harassment and physical attack'. Various laws are used in this regard (Amnesty International, 2019c; Humanists International, 2020d; Freedom House, 2020e):

- Provisions in the Criminal Code punishing sedition and defamation.

- Provisions under the 2016 Computer-Related Crime Act which allow the Government to prosecute individuals for spreading 'false' or 'distorted' information. 
- The 2019 Cybersecurity Law and Data Protection Act allowing the Government to increase online surveillance and censorship, without basic legal safeguards.

- The Anti-Fake News Centre launched in 2019, and mandated to monitor online content, filter out anything deemed 'fake news', and take action against users who post such content.

Amnesty International (2019c) reports that the above laws/measures have been used to target, among others, opposition politicians, academics, factory workers, and activists. It describes the kinds of activities they were charged for: participating in 'activities such as marching in peaceful demonstrations, discussing political reform, or criticising the monarchy or the Government, including on social media. At least 21 people were prosecuted for wearing t-shirts or displaying flags associated with a movement proposing a federal political system' (Amnesty International, 2019c). The Government has also pressured social media platforms to restrict access to content critical of the monarchy or the military (Amnesty International, 2019c).

There are two further significant restrictions on freedom of expression and speech: in relation to the monarch, and to Buddhism. The king is traditionally revered in Thai culture as the protector of the country and of the Buddhist religion, and Article 112 of the Criminal Code (lèse-majesté) states that anyone who 'defames, insults or threatens the King or Queen or the heir apparent or the regent' will be punished with a jail term of up to 15 years' (Humanists International, 2020d: 3). Since 2014 (when the military took power in a coup), at least 90 people have been charged under the law (Humanists International, 2020d: 3). For example, in August 2017, a law student and activist was sentenced to two and a half years imprisonment for sharing a BBC profile of the new king on Facebook (Humanists International, 2020d: 3). Use of Article 112 decreased after 2018, but other legal provisions restricting freedom of expression (see above) are being used to prosecute critics of the monarchy (HRW, 2020c).

The Constitution prohibits speech likely to insult Buddhism (and other religions), while the Sangha Act specifically prohibits the defamation or insult of Buddhism and the Buddhist clergy (Humanists International, 2020d). Those found guilty of violating this law can face up to a year in prison or fines up to 20,000 Baht (approx. USD667) (Humanists International, 2020d: 3). The Penal Code also has sections which prohibit the insult or disturbance of religious places or services of all officially recognised groups, with penalties ranging from imprisonment of one to seven years or a fine of 2,000 to 14,000 Baht (Humanists International, 2020d: 3). Given that Buddhism is the overwhelming majority religion in Thailand, such restrictions largely apply to that religion.

Media freedom is curbed in Thailand using many of the legal instruments described above. According to Human Rights Watch (2020e), 'Outspoken media outlets and reporters faced intimidation and punishment for commentaries critical of the junta'. This is echoed by Freedom House (2020e): 'Under military rule, the Government systematically used censorship, intimidation, and legal action to suppress independent media, and international and domestic news media were frequently censored during the election campaign period in early 2019 . 
The transition to civilian rule in July 2019 does not appear to have improved the situation perhaps not surprising given that the former military ruler General Prayuth, became Prime Minister, Defence Minister and head of the Thai police (RSF, 2020e). In September 2019, a political commentator was fired from a radio station for making corruption allegations against the military, while in October a Belgian journalist was detained by the police and told not to pursue his investigative story about a string of violent attacks on pro-democracy activists (HRW, 2020e). In December 2019, a journalist was sentenced to two years in prison for tweeting about the conditions of migrant workers (RSF, 2020e). Moreover, several journalists charged under the military junta still face prosecution (Freedom House, 2020e). Reporters without Borders (RSF, 2020e) also assert that Thai authorities allow Cambodian, Chinese and Vietnamese operatives to come into Thailand and arrest dissident exile journalists or bloggers from their country in order to 'repatriate' and then jail them.

\section{Freedom of belief}

Only five religions are officially recognised by the law in Thailand: Buddhism, Islam, Hinduism, Sikhism and Christianity (Humanists International, 2020d). Atheism is not recognised, creating problems for non-religious people when accessing public services they must state their religious affiliation in the requisite forms and cannot leave the section blank (Humanists International, 2020d).

\section{Civil society freedom and under-represented groups}

According to Freedom House (2020e) civil society groups 'focused on defending human rights and freedom of expression, and promoting democracy, continue to face restrictions, criminalization and prosecution by the state, including under sedition and lèse majesté laws'. Pro-democracy activists were attacked by gangs thought to be connected to the military following elections in March 2019 (Freedom House, 2020e). Human Rights Watch (2020c) notes that, 'The government has not seriously investigated these attacks and instead told activists and dissidents to give up political activity if they wanted state protection'. Civil society groups that promote republicanism, e.g., the Organization for Thai Federation, are forbidden (Freedom House, 2020e).

As in the Philippines, land rights and environmental activists in Thailand risk serious and even deadly violence: Global Witness described Thailand as among the most dangerous countries in Asia for such activists to operate (Freedom House, 2020e). In September 2019, skull fragments found in a national park were identified as belonging to a Karen environmental activist who was last seen in the park in the custody of government park officials in April 2014 (Freedom House, 2020e). Arrest warrants for four park officials wanted in connection with the abduction and murder were issued in November 2019.

Humanists International (2020d: 2) note that the 'attachment to traditional religious values translates into conservative views on gender roles and non-conformist sexualities'. With regards to LGBT+ rights, 'religion negatively affects the perception of non-conformist sexual orientation and gender identities: Theravada Buddhism views them 'either as a punishment for sins in past lives, or as a lack of ability to control sexual impulses and tendencies' (Humanists International, 2020d: 2). There is widespread discrimination against LGBT+ people, by families and society, employers and the authorities. The situation for LGBT+ people is worse in southern provinces of the country with a strong Islamic population. However, according to Freedom House (2020e), 'Thailand is known for its tolerance of LGBT+ people, though societal acceptance is higher for tourists and expatriates than for nationals, and unequal treatment and stigmatization remain challenges'. A draft law, the Life 
Partners Act, would if passed, be an important step towards recognising same-sex couples and giving them important legal protections (HRW, 2020e).

Also marginalised in Thailand are indigenous hill communities in the north of the country. These are 'not fully integrated into society. Many lack formal citizenship, which renders them ineligible to vote, own land, attend state schools, or receive protection under labour laws' (Freedom House, 2020e). 


\section{References}

AFP in Washington (2020, April 28). India should be placed on religious freedom blacklist. The Guardian. https://www.theguardian.com/world/2020/apr/28/india-religious-freedomnarendra-modi-us

Alum, R. (2018). The compromised state of civil society in Bangladesh. Civicus. https://www.civicus.org/index.php/re-imagining-democracy/stories-from-thefrontlines/3342-the-compromised-state-of-civil-society-in-bangladesh

Amnesty International (2017). Caught between Fear and Repression: Attacks on Freedom of Expression in Bangladesh. Amnesty International. https://www.amnesty.org/en/documents/asa13/6114/2017/en/

Amnesty International (2019a). India. Amnesty International. https://www.amnesty.org/en/countries/asia-and-the-pacific/india/

Amnesty International (2019b). Indonesia 2019. Amnesty International. https://www.amnesty.org/en/countries/asia-and-the-pacific/indonesia/report-indonesia/

Amnesty International (2019c). Philippines 2019. Amnesty International. https://www.amnesty.org/en/countries/asia-and-the-pacific/philippines/report-philippines/

Amnesty International (2019d). Thailand 2019. Amnesty International. https://www.amnesty.org/en/countries/asia-and-the-pacific/thailand/report-thailand/

Article 19 (2020, May 19). Bangladesh: Alarming crackdown on freedom of expression during coronavirus pandemic. https://www.article19.org/resources/bangladesh-alarmingcrackdown-on-freedom-of-expression-during-coronavirus-pandemic/

Asia Foundation (2017). The state of conflict and violence in Asia: Indonesia. Asia Foundation. https://asiafoundation.org/wp-content/uploads/2017/10/IndonesiaStateofConflictandViolence.pdf

BIISS \& Saferworld (2009). Climate change and security in Bangladesh: A case study. Bangladesh Institute of International and Strategic Studies (BIISS) and Saferworld. https://www.files.ethz.ch/isn/103629/Bangladesh_climat_change_June09.pdf

Blondel, A. (2012). Climate change fuelling resource-based conflicts in the Asia-Pacific. UNDP. https://www.uncclearn.org/wp-content/uploads/library/undp304.pdf

Caruso, R., Petrarca, I. \& Riciuti, R. (2016). Climate change, rice crops and violence: Evidence from Indonesia. Journal of Peace Research, 53(1), 66-83. https://journals.sagepub.com/doi/pdf/10.1177/0022343315616061?casa_token=iL_E8tN2h RMAAAAA:RoPht15wZPUahVxj3AF73q6QwrEInfYdHZoqjemY5phXY3PK8T7zGHC6zKKN RjUI0TKkVyyrGq40

Chachavalpongpun, P. \& Kurlantzick, J. (2020, October 28). The Thai king sends messages presaging conflict in Thailand. Council on Foreign Relations (CFR). https://www.cfr.org/blog/thai-king-sends-messages-presaging-conflict-thailand

CEP (2020). Bangladesh: Extremism and Counter-Extremism. Counter Extremism Project (CEP). https://www.counterextremism.com/sites/default/files/country_pdf/BD06152020.pdf 
Dunne, D. (2019, March 27). The Carbon Brief Profile: Indonesia. Carbon Brief. https://www.carbonbrief.org/the-carbon-brief-profile-indonesia

Fetzek, S. \& McGinn, D. (2020, August 10). Climate change is a security threat to the IndoPacific. The Diplomat. https://thediplomat.com/2020/08/climate-change-is-a-securitythreat-to-the-asia-pacific/

Freedom House (2020a). Freedom in the World 2020: Bangladesh. Freedom House. https://freedomhouse.org/country/bangladesh/freedom-world/2020

Freedom House (2020b). Freedom in the World 2020: India. Freedom House. https://freedomhouse.org/country/india/freedom-world/2020

Freedom House (2020c). Freedom in the world 2020: Indonesia. Freedom House. https://freedomhouse.org/country/indonesia/freedom-world/2020

Freedom House (2020d). Freedom in the World 2020: The Philippines. Freedom House. https://freedomhouse.org/country/philippines/freedom-world/2020

Freedom House (2020e). Freedom in the World 2020: Thailand. Freedom House. https://freedomhouse.org/country/thailand/freedom-world/2020

Froese, R. \& Schilling, J. (2019). The nexus of climate change, land use and conflicts. Current Climate Change Reports. 5, 24-35. https://doi.org/10.1007/s40641-019-00122-1

Germanwatch (2020). Global Climate Risk Index 2020. Germanwatch. https://www.germanwatch.org/sites/germanwatch.org/files/20-201e\%20Global\%20Climate\%20Risk\%20Index\%202020_14.pdf

Hamid, U. (2019, November 25). Indonesia's Information Law has threatened freedom of speech for more than a decade. This must stop. The Conversation. https://theconversation.com/indonesias-information-law-has-threatened-free-speech-formore-than-a-decade-this-must-stop-127446

Harsono, A. (2020, April 11). 'Religious harmony’ regulation brings anything but. The Jakarta Post. https://www.thejakartapost.com/academia/2020/04/11/religious-harmony-regulationbrings-anything-but.html

Henschke, R. \& Utama, A. (n.d.). When your capital is sinking...start again? BBC News. https://www.bbc.co.uk/news/extra/xsyGF2fhsL/Indonesia_new_capital

Herbert, S. (2019a). Conflict Analysis of Bangladesh. K4D Helpdesk Report 599. Institute of Development Studies (IDS). https://opendocs.ids.ac.uk/opendocs/bitstream/handle/20.500.12413/15377/599_Banglade sh_Conflict_Analysis.pdf?sequence=1\&isAllowed=y

Herbert, S. (2019b). Conflict analysis of the Philippines. K4D Helpdesk Report. Institute of Development Studies (IDS). https://opendocs.ids.ac.uk/opendocs/bitstream/handle/20.500.12413/14661/648_Conflict_ Analysis_of_The_Philippines.pdf?sequence $=1$ \&isAllowed $=\mathrm{y}$

HRW (2020a). Bangladesh: Events of 2019. Human Rights Watch (HRW). https://www.hrw.org/world-report/2020/country-chapters/bangladesh

HRW (2020b). India: Events of 2019. Human Rights Watch (HRW). https://www.hrw.org/world-report/2020/country-chapters/india 
HRW (2020c). Indonesia Events of 2019. Human Rights Watch (HRW).

https://www.hrw.org/world-report/2020/country-chapters/indonesia

HRW (2020d). Philippines Events of 2019. Human Rights Watch (HRW). https://www.hrw.org/world-report/2020/country-chapters/philippines

HRW (2020e). Thailand Events of 2019. Human Rights Watch (HRW). https://www.hrw.org/world-report/2020/country-chapters/thailand

Humanists International (2020a, October 13). Freedom of Thought Report: Bangladesh. Humanists International. https://fot.humanists.international/countries/asia-southernasia/bangladesh/

Humanists International (2020b, October 26). Freedom of Thought report: Indonesia. Humanists International. https://fot.humanists.international/countries/asia-south-easternasia/indonesia/

Humanists International (2020c, October 27). Freedom of Thought report: Philippines. Humanists International. https://fot.humanists.international/countries/asia-south-easternasia/philippines/

Humanists International (2020d). Freedom of Thought report: Thailand. Humanists International. https://fot.humanists.international/countries/asia-south-eastern-asia/thailand/

Huntjens, P. \& Nachbar, K. (2015). Climate change as a threat multiplier for human disaster and conflict. Working Paper 9. The Hague Institute for Global Justice. https://www.thehagueinstituteforglobaljustice.org/wp-content/uploads/2015/10/workingPaper-9-climate-change-threat-multiplier.pdf

Hutt, D. (2016, February 11). Nationalism and the rise of Buddhist extremism. Southeast Asia Globe. https://southeastasiaglobe.com/thai-nationalism-and-the-rise-of-buddhistextremism/?pico_new_user=false\&pico_ui=login_link

ICG (2016). Political Conflict, Extremism and Criminal Justice in Bangladesh. Asia Report No. 277. International Crisis Group (ICG). https://d2071andvip0wj.cloudfront.net/277political-conflict-extremism-and-criminal-justice-in-bangladesh.pdf

Idris, I. (2017). Rohingya crisis: impact on Bangladeshi politics. K4D Helpdesk Report 233. Institute of Development Studies. https://gsdrc.org/publications/rohingya-refugee-crisisimpact-on-bangladeshi-politics/

IMCCS (2020). Climate and Security in the Indo-Asia Pacific. International Military Council on Climate and Security (IMCCS). https://imccs.org/wp-content/uploads/2020/07/ClimateSecurity-Indo-Asia-Pacific_2020_7.pdf

Kamdar, M. (2018, April 23). Do Indians have freedom of speech? Pacific Council on International Policy. https://www.pacificcouncil.org/newsroom/do-indians-have-freedomspeech

Kisner, C. (2008). Climate change in Thailand: Impacts and adaptation strategies. Climate Institute. https://climate.org/archive/topics/international-action/thailand.htm

Marks, D. (2011). Climate change and Thailand: Impact and response. Contemporary Southeast Asia A Journal of International and Strategic Affairs, 33(2), 229-258. https://www.researchgate.net/publication/236751238_Climate_Change_and_Thailand_Imp act_and_Response 
MoFA (2018). Climate Change Profile Indonesia. Ministry of Foreign Affairs of the Netherlands (MoFA).

https://reliefweb.int/sites/reliefweb.int/files/resources/Indonesia_2.pdf

Morch, M. (2018, February 6). The slow burning insurgency in Thailand's deep south. The Diplomat. https://thediplomat.com/2018/02/the-slow-burning-insurgency-in-thailands-deepsouth/

Newman, S. (2014, June 27). Will climate change spark conflict in Bangladesh? The Diplomat. https://thediplomat.com/2014/06/will-climate-change-spark-conflict-inbangladesh/

Nordqvist, P. \& Krampe, F. (2018). Climate change and violent conflict: Sparse evidence from South and Southeast Asia. Stockholm International Peace Research Institute (SIPRI). https://www.sipri.org/sites/default/files/2018-09/sipriinsight1804.pdf

Ochab, E. (2019, January 12). Religious freedom is on the decrease in India. Forbes. https://www.forbes.com/sites/ewelinaochab/2019/01/12/religious-freedom-is-on-thedecrease-in-india/?sh=310d1ccd403b

Open Development Thailand (2018, February 12). Climate Change. Open Development Thailand. https://thailand.opendevelopmentmekong.net/topics/climate-change/

RSF (2020a). Bangladesh. Reporters without Borders (RSF). https://rsf.org/en/bangladesh

RSF (2020b). India. Reporters without Borders (RSF). https://rsf.org/en/india

RSF (2020c). Indonesia. Reporters without Borders (RSF). https://rsf.org/en/indonesia

RSF (2020d). Philippines. Reporters without Borders (RSF). https://rsf.org/en/philippines

RSF (2020e). Thailand. Reporters without Borders (RSF). https://rsf.org/en/thailand

Peters, K. et al (2020). Climate change, conflict and fragility. An evidence review and recommendations for research and action. Overseas Development Institute (ODI). https://www.odi.org/sites/odi.org.uk/files/resourcedocuments/odi_climate_change_conflict_and_fragility.pdf

SIDA (2018). The relationship between climate change and violent conflict. Swedish International Development Cooperation Agency (SIDA). https://www.sida.se/contentassets/c571800e01e448ac9dce2d097ba125a1/working-paper--climate-change-and-conflict.pdf

USAID (2017a). Climate Change Risk Profile Philippines. USAID.

https://www.climatelinks.org/sites/default/files/asset/document/2017_Climate\%20Change\% 20Risk\%20Profile_Philippines.pdf

USAID (2017b). Climate Risk Profile India. USAID. https://www.climatelinks.org/sites/default/files/asset/document/2017_USAID\%20ATLAS_CI imate\%20Risk\%20Profile\%20-\%20India.pdf

USAID (2017c). Climate Risk Profile Indonesia. USAID. https://www.climatelinks.org/sites/default/files/asset/document/2017_USAID_ATLAS_Clim ate\%20Risk\%20Profile_Indonesia.pdf

USAID (2018). Climate Risk Profile: Bangladesh. USAID. https://www.climatelinks.org/resources/climate-risk-profile-bangladesh 
van Baalen, S. \& Mobjork, M. (2016). A Coming Anarchy? Pathways from climate change to violent conflict in East Africa. Stockholm University.

https://www.statsvet.su.se/polopoly_fs/1.282383.1464852768!/menu/standard/file/van\%20 Balen\%20\%26\%20Mobj\%C3\%B6rk\%20160511.pdf

Van der Vuurst, P. \& Escobar, L. (2020, January 20). Perspective: Climate change and the relocation of Indonesia's capital to Borneo. Frontiers in Earth Science.

https://www.frontiersin.org/articles/10.3389/feart.2020.00005/full 